\title{
Inflows and river heights in Australia's Murray Darling Basin: impacts of decreased catchment rainfall on water availability.
}

Milton Speer ( $\sim$ Milton.Speer@uts.edu.au )

University of Technology Sydney

Lance Leslie

University of Technology Sydney

Shev MacNamara

University of Technology Sydney

Joshua Hartigan

University of Technology Sydney

\section{Research Article}

Keywords: Murray Darling Basin, Murrumbidgee River, catchment rainfall and inflows, statistical analysis, water availability, climate impacts

Posted Date: February 19th, 2021

DOl: https://doi.org/10.21203/rs.3.rs-209141/v1

License: (9) This work is licensed under a Creative Commons Attribution 4.0 International License.

Read Full License

Version of Record: A version of this preprint was published at Scientific Reports on August 9th, 2021. See the published version at https://doi.org/10.1038/s41598-021-95531-4. 


\section{Inflows and river heights in Australia's Murray Darling Basin:} impacts of decreased catchment rainfall on water availability.

$4 \quad{ }^{1}$ School of Mathematical and Physical Sciences, University of Technology, Sydney,

5 Australia

6 L.M.Leslie: Lance.Leslie@uts.edu.au; S.MacNamara: Shev.MacNamara@uts.edu.au;

$7 \quad$ Joshua.Hartigan@student.uts.edu.au

8 *corresponding author: - Dr Milton Speer, School of Mathematical and Physical

9 Sciences, University of Technology Sydney, PO Box 123, Broadway, NSW Australia $10 \quad 2007$

11 Email: Milton.Speer@uts.edu.au

12 
The Murray Darling Basin (MDB) is Australia's most important agricultural region. The southern MDB receives most of its annual catchment runoff during the cool season (April-September). Focusing on the Murrumbidgee River measurements at Wagga Wagga and further downstream at Hay, river

\section{Introduction}

37 The Murray-Darling River basin (MDB), located in south eastern Australia, is Australia's 
most important agricultural area, producing almost $40 \%$ of the national food supply ${ }^{[1]}$. In comparison, the agricultural area of the central valley of California provides approximately $20 \%$ of the total US food production ${ }^{[2]}$. Drought conditions since the mid1990s in the MDB have resulted in rivers running dry and low water storages, affecting communities, businesses, animals, and the environment. The southern half of the MDB, in which the Murrumbidgee River catchment is located (Fig.1), occupies a large geographical area of southeast Australia where the growing season is in the cooler half of the year (April-September) ${ }^{[3]}$. To ensure the supply of catchment rainfall, it is crucial to receive average or close to average rainfall during this period. Along the catchment Burrinjuck Dam and Blowering Dam receive 57\%, Tumut 56\%, Wagga Wagga 52\% and Hay $52 \%$ of their annual average rainfall in this period. Notably, stream flows have been declining across the MDB, particularly since the 1970s (Figs.2a,b).

Fig. 1. The Murrumbidgee River and catchment area. (hatched black). Snowy Mountains Hydroelectric Scheme (hatched blue). The inset identifies the catchment location in southeast Australia.

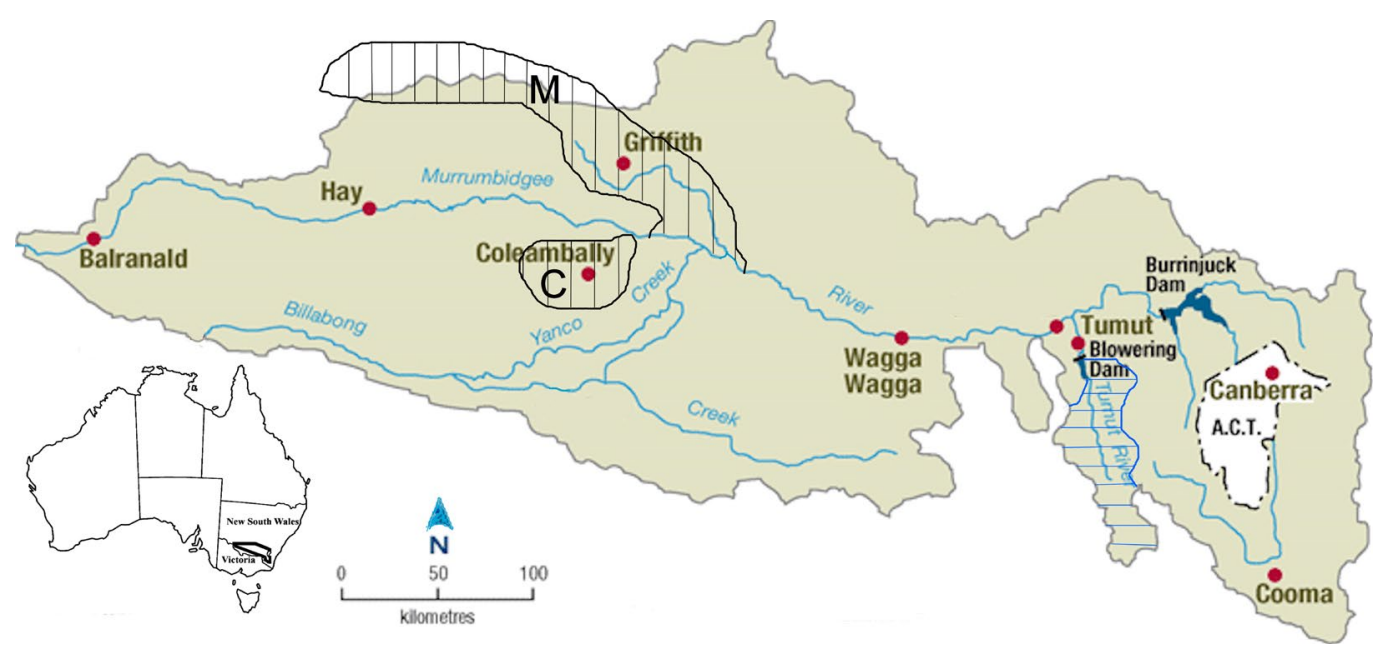




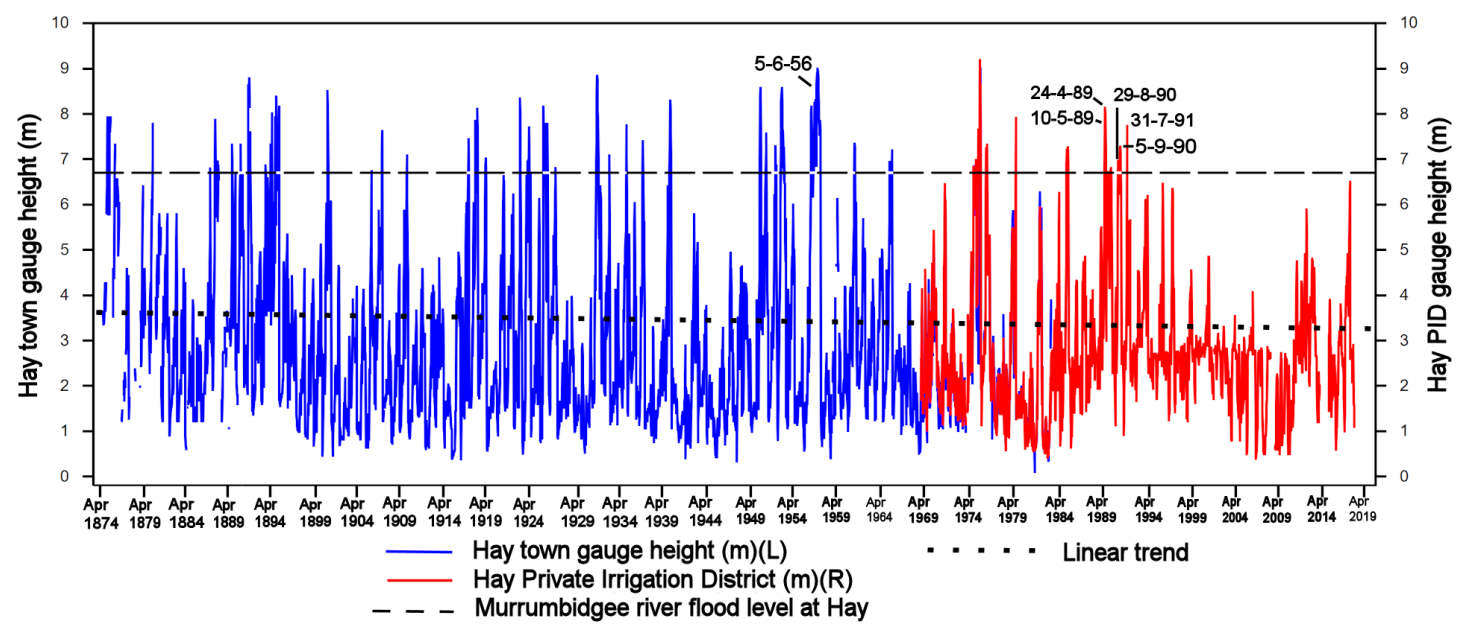

Fig.2a Murrumbidgee river heights (m) at the Hay town gauge and Hay PID for

(April-September) 1874 to 2019. There are concurrent readings at the two locations 1991), are designated.

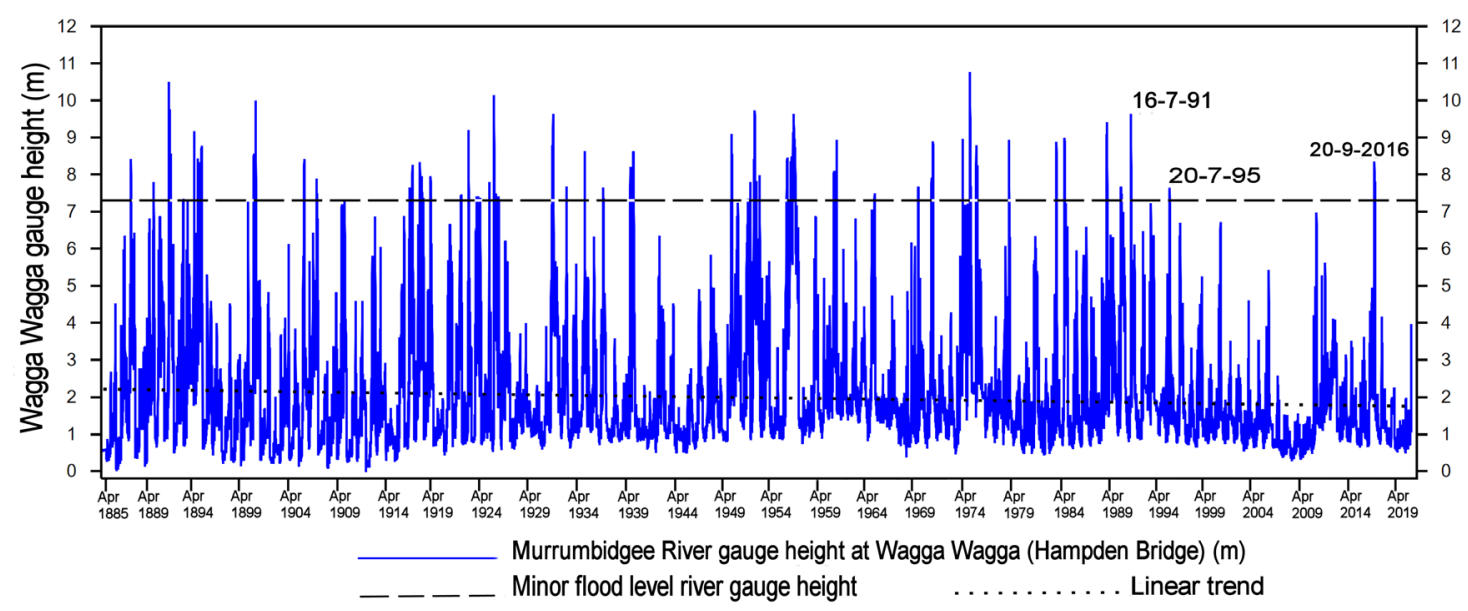

Fig.2b Murrumbidgee river heights at Wagga Wagga (April to September) 1885minor flood levels reached since 1991 are marked. 


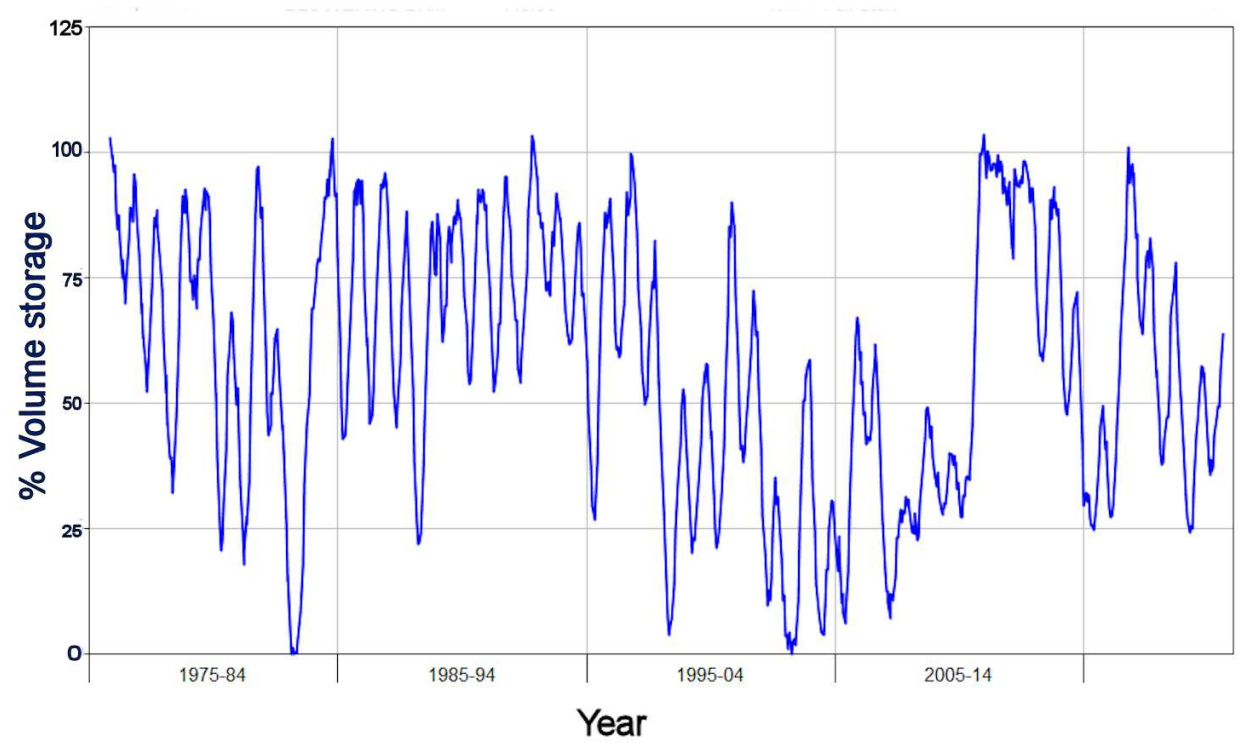

69

70 Fig.2c Annual volume storage (\%) for Blowering Dam indicating precipitation 71 inflows from 1975-2019.

72

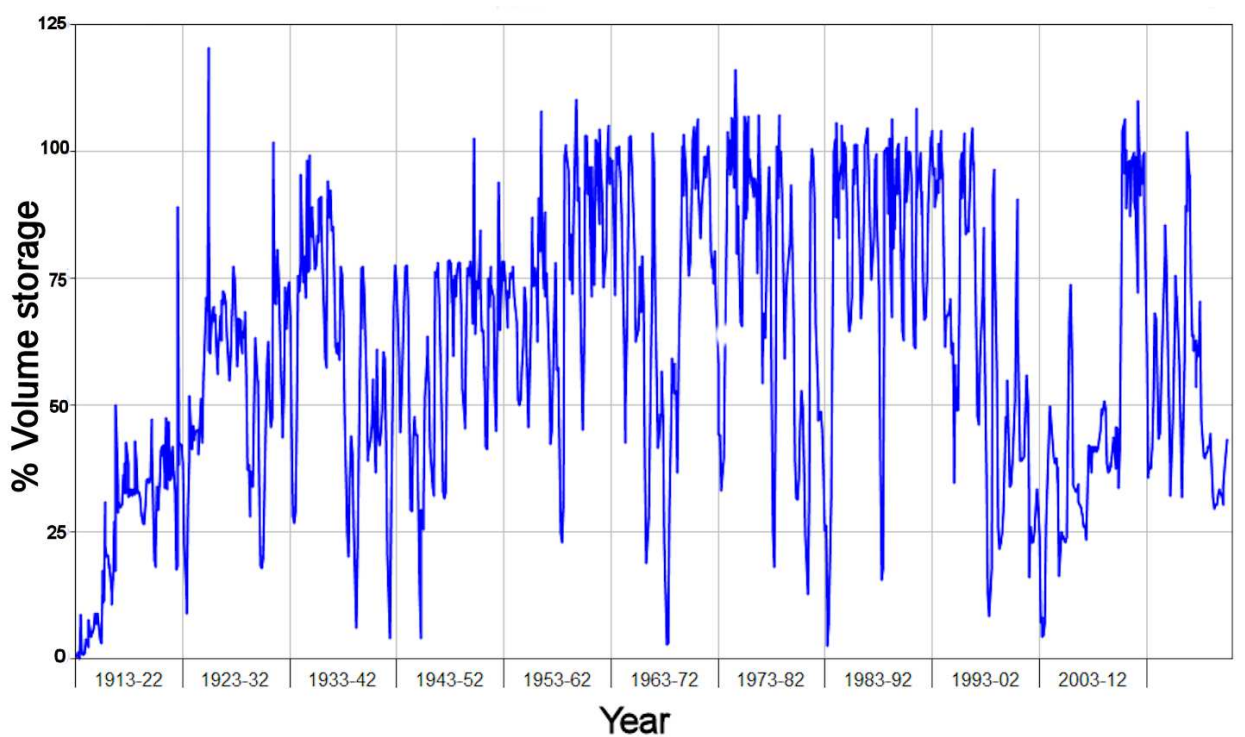

74 Fig.2d Annual volume storage (\%) for Burrinjuck Dam indicating precipitation inflows from 1913-2019.

Aside from the current drought, starting from 2013, the MDB previously experienced major multi-year droughts in 1997-2009 (Millennium Drought), 1938- 

downward trends in rainfall since the 1990s in southern parts of eastern Australia, and in the higher rainfall areas of the MDB that generally are located in the highlands of the Great Dividing Range ${ }^{[4]}$. These trends are concentrated in the winter or cool season half of the year from April to September ${ }^{[3]}$. A major influence on this drying trend has been the strengthening and extension of the subtropical high pressure ridge during winter, which shifts rain-bearing weather systems southward ${ }^{[4,5]}$. Specifically, the lack of negative-phase Indian Ocean Dipole (IOD) events has been identified as a contributing factor to the drying and drought in the southeast since the $1990 \mathrm{~s}^{[6]}$, the region of Australia where the influence of the IOD is greatest in the June-October period ${ }^{[7]}$. Prior to the 1990s, the main regulation of the Murrumbidgee River upstream of Hay occurred over two periods during which large storages were built. These were the Burrinjuck Dam in 1910-1927 and Blowering Dam 1956-1961 (Fig.1). Before the Burrinjuck Dam was built, annual river flows at Hay followed a pattern of variability and quantity similar to annual river flows measured at Wagga Wagga (Fig.1). After the Burrinjuck Dam was built (1928), the water flows diverged in quantity although annual patterns of variability coincided ${ }^{[8]}$. After the Blowering Dam construction was completed in the 1960s, the relationship between river flows at Wagga Wagga and Hay were affected. There were similar patterns of variability but there was a substantial difference in the quantity of water reaching Hay from Wagga Wagga, compared with that before river regulation ${ }^{[8,9]}$. It was concluded that there was a $56 \%$ reduction in the

100 lower Murrumbidgee River at Hay ${ }^{[10]}$, which occurred mostly after 1957 when there was a change point between low regulated flow and high regulated flow. Even after the 1957 change point, river flows were seasonal, driven by reliable winter and spring rainfall together with headwater ice and snow melt, and much of the flow reached the 
104 floodplain below Hay ${ }^{[8]}$. However, there has been a sharp drop to zero in JJAS

105 Murrumbidgee River flooding events at Hay since 1991 (Fig. 2a) and one only minor

106 flood in 1995 at Wagga Wagga (Fig.2b), in addition to much reduced dam inflows since

107 the mid-1990s (Figs.2c, d). In Figure 2a there is a data overlap of about 13 years at Hay

108 town gauge and Hay Private Irrigation District (PID) gauge for which the mean height

109 is the same and data quality is good taking into account missing values, outliers,

110 continuity between the two gauge locations and measurement practice ${ }^{[11]}$. The flooding

111 level of $6.7 \mathrm{~m}$ at Hay is defined as the level above which water starts to spill over the

112 riverbanks at Hay ${ }^{[11]}$ and the minor flood level at the river gauge at Wagga Wagga is

$1137.3 \mathrm{~m}$.

114 It is hypothesized here that from the mid-1990s the main influence on decreased

115 downstream river water availability is due to the reduction in dam inflows from

116 decreased precipitation. It is well-known that rainfall in southeast Australia, where the

117 Murrumbidgee River catchment is located, usually is highest in winter and has a

118 minimum through summer into early autumn ${ }^{[3]}$. Hence the so-called 'winter cropping

119 season' starts with planting in autumn and harvesting in spring-summer. Most river

120 height exceedances above $6.7 \mathrm{~m}$ at Hay in JJAS occur in July, August and September

121 (Table 1a) after sufficient catchment wetting. Spring (SON) floods are the most

122 common (Table $1 \mathbf{b}$ ) as river and dam inflows are a result of both rainfall and snowmelt.

123 However, since 1991 there has been just one April to September flood at both Hay and

124 Wagga Wagga resulting from Burrinjuck Dam overspill which was in September 2016

125 (Table 1b). Extreme SON precipitation totals are associated with La Niña over eastern

126 Australia ${ }^{[12]}$. In terms of river flood events at Hay and Wagga Wagga, and inflows at

127 the catchment dams of Burrinjuck and Blowering in southeast Australia, this

128 relationship broke down, as shown by the presence only of neutral phases of ENSO 
129 after the 1970s (Table 1b) and in agreement with eastern Australian rainfall in general

$130 \quad[12]$

131

132

\begin{tabular}{|l|l|l|l|l|l|}
\hline YEAR & Jun & JuI & Aug & Sept & $\begin{array}{l}\text { JJAS } \\
\text { count }\end{array}$ \\
\hline $\mathbf{1 8 7 4}$ & & 7.92 & 7.92 & 7.92 & 3 \\
\hline $\mathbf{1 8 7 5}$ & 7.25 & 7.32 & & & 2 \\
\hline $\mathbf{1 8 7 6}$ & & & & 8.0 & 1 \\
\hline $\mathbf{1 8 8 7}$ & & 7.86 & & 7.22 & 2 \\
\hline $\mathbf{1 8 8 9}$ & & 7.32 & & 7.31 & 2 \\
\hline $\mathbf{1 8 9 0}$ & & & & & \\
\hline $\mathbf{1 8 9 1}$ & & 8.78 & 7.62 & 6.9 & 2 \\
\hline $\mathbf{1 8 9 3}$ & & 6.86 & 8.3 & & 2 \\
\hline $\mathbf{1 8 9 4}$ & & 6.71 & 8.38 & 8.3 & 3 \\
\hline $\mathbf{1 9 0 5}$ & & & 6.74 & & 1 \\
\hline $\mathbf{1 9 0 6}$ & & & & 7.62 & 1 \\
\hline $\mathbf{1 9 0 9}$ & & & & 7.08 & 1 \\
\hline $\mathbf{1 9 1 6}$ & & & & 7.43 & 1 \\
\hline $\mathbf{1 9 1 7}$ & & & 7.85 & 8.1 & 2 \\
\hline $\mathbf{1 9 1 8}$ & & & 6.89 & 8.1 & 2 \\
\hline $\mathbf{1 9 2 2}$ & & & 8.33 & & \\
\hline $\mathbf{1 9 2 3}$ & & 6.94 & 7.69 & 6.7 & 3 \\
\hline $\mathbf{1 9 2 5}$ & 8.15 & 7.77 & & 7.77 & 3 \\
\hline $\mathbf{1 9 2 6}$ & & & 6.81 & & 1 \\
\hline $\mathbf{1 9 3 1}$ & 8.33 & 8.83 & 6.7 & & 3 \\
\hline $\mathbf{1 9 3 2}$ & & & & 7.08 & 1 \\
\hline $\mathbf{1 9 3 4}$ & & & & 7.74 & 1 \\
\hline $\mathbf{1 9 3 6}$ & & & 7.39 & & 1 \\
\hline $\mathbf{1 9 3 9}$ & & & & 8.2 & 1 \\
\hline $\mathbf{1 9 4 9}$ & & & 7.56 & & 1 \\
\hline $\mathbf{1 9 5 0}$ & & & 7.55 & & 1 \\
\hline $\mathbf{1 9 5 1}$ & & & & 6.85 & 1 \\
\hline $\mathbf{1 9 5 2}$ & 8.22 & 8.56 & 7.62 & & 3 \\
\hline $\mathbf{1 9 5 5}$ & & & & 8.15 & 1 \\
\hline $\mathbf{1 9 5 6}$ & 8.31 & 8.99 & 8.78 & 7.84 & 4 \\
\hline $\mathbf{1 9 6 0}$ & & & 7.35 & 6.82 & 2 \\
\hline $\mathbf{1 9 6 4}$ & & & 6.93 & 7.19 & 2 \\
\hline $\mathbf{1 9 7 4}$ & & 7.24 & 7.35 & 8.99 & 3 \\
\hline $\mathbf{1 9 8 4}$ & & & 7.2 & 7.26 & 2 \\
\hline $\mathbf{1 9 8 9}$ & & 6.72 & 6.8 & & 2 \\
\hline $\mathbf{1 9 9 0}$ & & 6.96 & 7 & 7.27 & 3 \\
\hline $\mathbf{1 9 9 1}$ & & 7.73 & & & 1 \\
\hline & & & & \\
\hline
\end{tabular}

133

Table 1a Table showing wet season (JJAS) monthly maximum weekly Murrumbidgee river heights at Hay (southern MDB) that exceed/equal flood level $(6.7 \mathrm{~m})$, and seasonal 134 count, in the 125 years $1874-2018$. 


\begin{tabular}{|c|c|c|c|c|c|}
\hline YEAR & Sep. & Oct. & Nov. & $\begin{array}{l}\text { SON } \\
\text { Total } \\
\text { count }\end{array}$ & $\begin{array}{l}\text { ENSO } \\
\text { Strength \& } \\
\text { sign }\end{array}$ \\
\hline 1874 & 7.92 & 7.77 & & 2 & N/A \\
\hline 1877 & & & 8.17 & 1 & mod. \\
\hline 1878 & & 8.99 & 7.92 & 2 & mod-strong + \\
\hline 1879 & 8.0 & & & 1 & very strong + \\
\hline 1886 & 6.95 & & & 1 & $\bmod$ \\
\hline 1887 & 7.22 & & & 1 & very strong + \\
\hline 1888 & & 7.65 & & 1 & mod. \\
\hline 1889 & 7.31 & & & 1 & mod. \\
\hline 1890 & 6.7 & & & 1 & strong \\
\hline 1891 & 6.9 & 7.16 & 7.01 & 3 & weak \\
\hline 1893 & & 7.25 & & 1 & mod-strong + \\
\hline 1894 & 8.3 & & & 1 & very strong + \\
\hline 1905 & & 8.08 & & 1 & mod. \\
\hline 1906 & 7.62 & 8.08 & & 2 & mod. \\
\hline 1909 & 7.08 & & & 1 & weak \\
\hline 1916 & 7.43 & 8.2 & & 2 & mod. \\
\hline 1917 & 8.11 & 8.31 & 8.31 & 3 & very strong + \\
\hline 1918 & 7.01 & & & 1 & weak \\
\hline 1923 & 6.7 & 6.93 & & 2 & mod. \\
\hline 1925 & 7.77 & & & 1 & $\bmod$ \\
\hline 1932 & 7.08 & & & 1 & weak \\
\hline 1934 & 7.74 & & 8.29 & 2 & NEUTRAL \\
\hline 1939 & 8.29 & & & 1 & weak \\
\hline 1950 & & & 8.31 & 1 & mod-strong + \\
\hline 1951 & 6.85 & 7.54 & & 2 & NEUTRAL \\
\hline 1952 & & 7.8 & 7.8 & 2 & NEUTRAL \\
\hline 1955 & 8.15 & & 7.13 & 2 & mod. \\
\hline 1956 & 7.84 & 7.96 & 8.23 & 3 & weak \\
\hline 1959 & & & 7.07 & 1 & NEUTRAL \\
\hline 1960 & 6.82 & 8.41 & & 2 & weak \\
\hline 1964 & 7.19 & 8 & 7.35 & 3 & weak \\
\hline 1970 & & 8.56 & & 1 & weak \\
\hline 1974 & 8.99 & 8.63 & 8.64 & 3 & weak \\
\hline 1975 & & & 8.62 & 1 & mod-strong + \\
\hline 1976 & & & 7.71 & 1 & NEUTRAL \\
\hline 1978 & & 7.6 & & 1 & NEUTRAL \\
\hline 1984 & 7.26 & 6.76 & & 2 & NEUTRAL \\
\hline 1990 & 7.27 & & & 1 & NEUTRAL \\
\hline 2016 & & 8.45 & & 1 & NEUTRAL \\
\hline
\end{tabular}

Table 1b. Table showing spring (SON) weekly maximum Murrumbidgee river heights at Hay (southern MDB) that exceed flood level $(6.7 \mathrm{~m})$, and seasonal count, in the 125 years 1874-2018. Also included is the strength of the ENSO signal as determined by the Australian Bureau of Meteorology (http://www.bom.gov.au/climate/enso/Inlist/index.shtml ). Note the neutral ENSO association with flood heights since the mid-1970s. In autumn (MAM) there are very few flood events (Table 1c) because the

140 catchment normally dries out sufficiently through summer to reduce river flow.

141 Monthly to seasonal precipitation typically exhibits large ranges due to its episodic

142 nature even if seasonal means show little change. Therefore, an important part of this 


\begin{tabular}{|l|l|l|l|l|}
\hline YEAR & Mar & Apr & May & $\begin{array}{l}\text { MAM } \\
\text { count }\end{array}$ \\
\hline $\mathbf{1 8 8 8}$ & & 6.8 & & 1 \\
\hline $\mathbf{1 8 9 4}$ & & 7.32 & 8.02 & 2 \\
\hline $\mathbf{1 9 5 0}$ & & 8.5 & 7.04 & 2 \\
\hline $\mathbf{1 9 5 6}$ & & 6.89 & 8.23 & 2 \\
\hline $\mathbf{1 9 7 4}$ & & & 6.85 & 1 \\
\hline $\mathbf{1 9 8 9}$ & & 8.41 & 7.93 & 2 \\
\hline $\mathbf{2 0 1 2}$ & 8.6 & & & 1 \\
\hline
\end{tabular}

143

144 Table 1c Table showing autumn (MAM) monthly maximum weekly

145 Murrumbidgee river heights at Hay (southern MDB) that exceed flood level $(6.7 \mathrm{~m})$, 146 and seasonal count in the 126 years 1874-2019.

147 (http://www.bom.gov.au/climate/enso/lnlist/index.shtml). Note the neutral ENSO

148 association with flood heights since the mid-1970s.

149

150 study is to analyse trends in the means and variances of catchment rainfall and inflows,

151 in addition to JJAS river heights at both Hay and Wagga Wagga. The focus is on the

152 period after the $1960 \mathrm{~s}$, since from then there has been no new regulatory infrastructure

153 upstream of Hay and particularly from the early to mid-1990s when the global warming

154 signal has accelerated ${ }^{[13]}$.

155 Considering changes in regulation of the Murrumbidgee River, box and whisker

156 plots and permutation testing are used to analyse changes in both JJAS and April-May

157 inflows at Burrinjuck/Blowering Dams, and precipitation at key rainfall catchment

158 locations including Burrinjuck Dam, Blowering Dam and Tumut, in addition to river

159 heights at both Hay and Wagga Wagga. Wavelets are then used to provide some

160 understanding of possible climate drivers affecting precipitation and inflows at these

161 locations, and how their influence has changed over time.

162

2. Results

164 As shown in Figs. 3(a-c), Burrinjuck Dam and Blowering Dam each records a mean

JJAS precipitation of about $300 \mathrm{~mm}$, while Tumut receives approximately $350 \mathrm{~mm}$. 
166 There are fewer percentiles near the extremes from the 1990s, with no years above the

$16795^{\text {th }}$ percentile apart from 2016 and a reduction in years below the $5^{\text {th }}$ percentile.

168 Statistical significance is discussed in the next section. Similarly, with April-May

169 precipitation there are no years above the $90^{\text {th }}$ percentile from the late $1990 \mathrm{~s}$ for the

170 three locations (Figs. 3d-f).

171

172 Fig. 3 Precipitation time series in the Murrumbidgee River catchment area. JJAS

173 precipitation at, a Burrinjuck Dam from 1910-2019, b Blowering Dam from 1955-2019

174 and c Tumut from 1883-2019; April-May precipitation at, d Burrinjuck Dam from

175 1910-2019, e Blowering Dam from 1955-2019 and, f Tumut from 1883-2019. Dashed

176 lines indicate percentiles $5^{\text {th }}$ and $95^{\text {th }}(\mathrm{red}) ; 10^{\text {th }}$ and $90^{\text {th }}$ (orange); $15^{\text {th }}$ and $85^{\text {th }}$ (light

177 blue); $20^{\text {th }}$ and $80^{\text {th }}$ (brown); and $25^{\text {th }}$ and $75^{\text {th }}$ (dark blue).

\section{Burrinjuck Precipitation - JJAS}

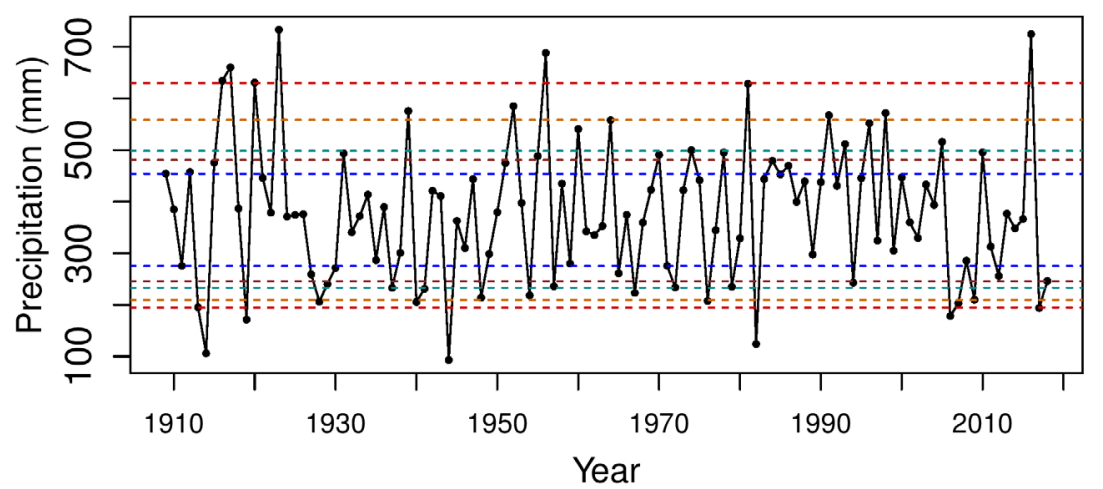

178

$179 \quad$ Fig.3(a)

180 


\section{Blowering Precipitation - JJAS}

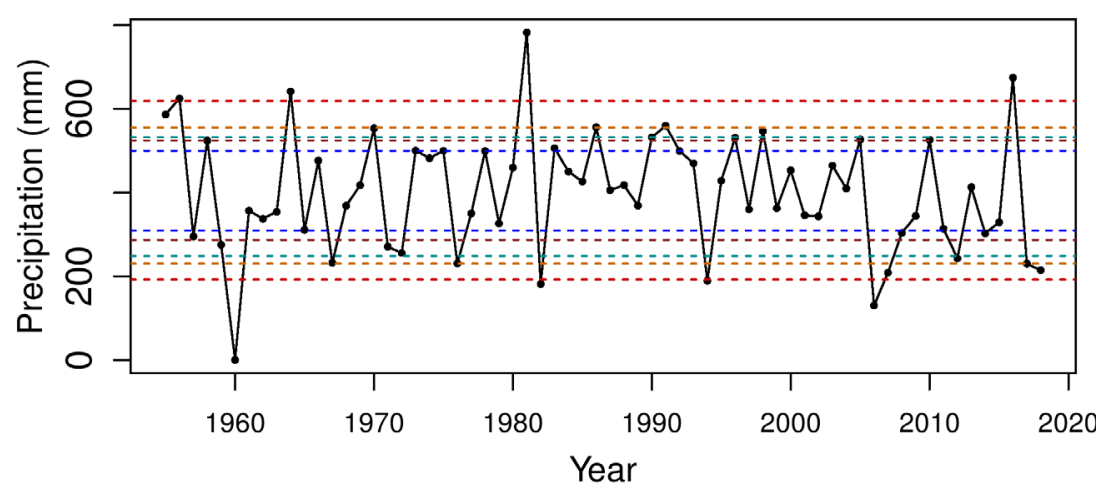

181

182 Fig.3(b)

Tumut Precipitation - JJAS

183

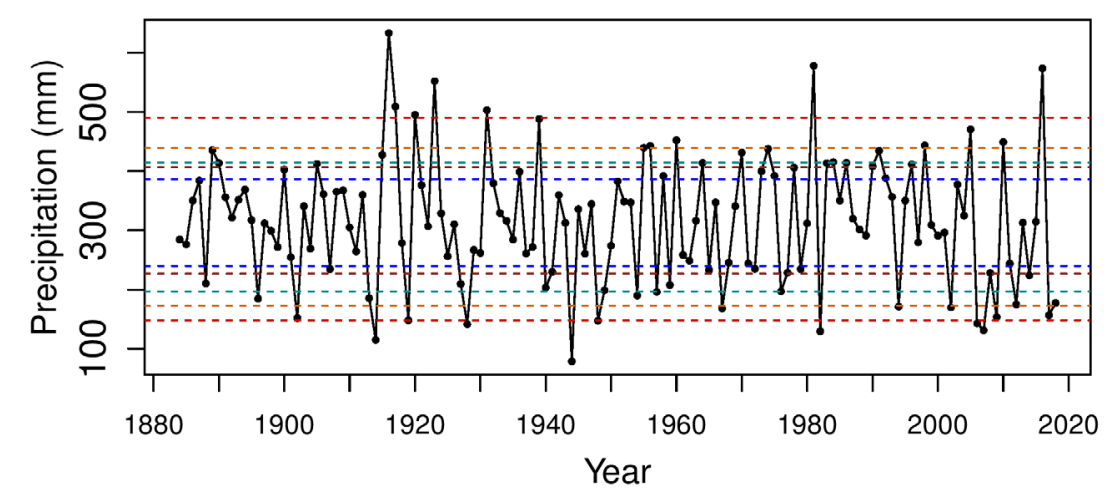

$184 \quad$ Fig.3(c)

Burrinjuck Precipitation - AM

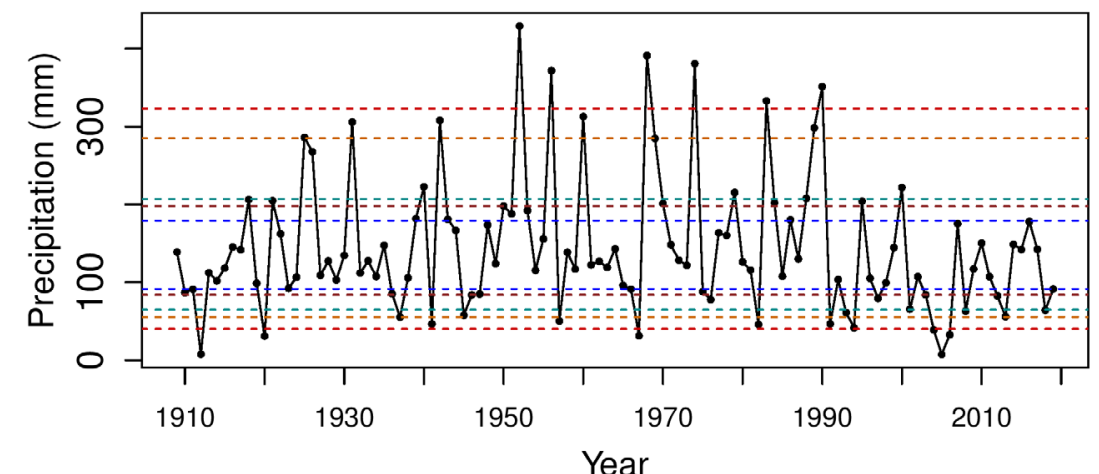

185 Year

$186 \quad$ Fig.3(d) 


\section{Blowering Precipitation - AM}

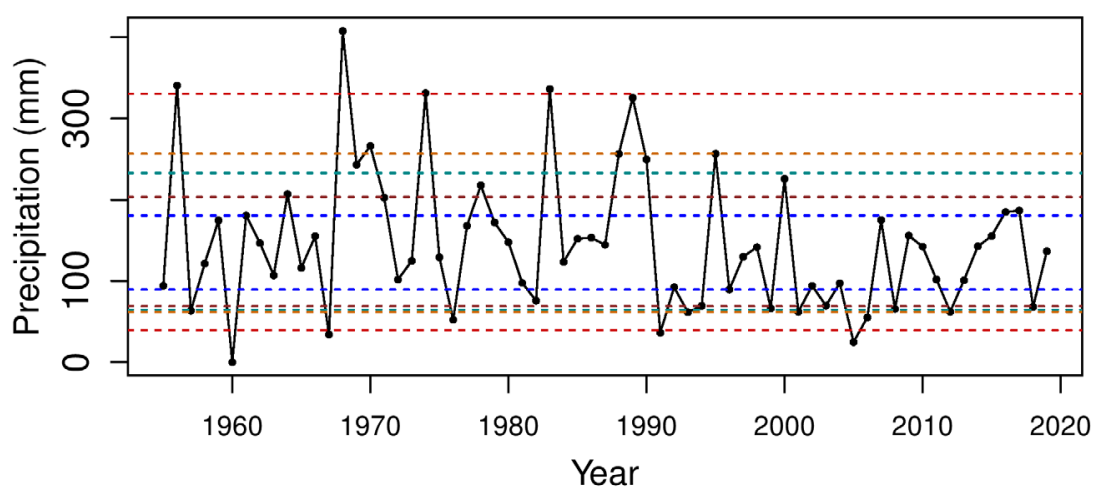

187

$188 \quad$ Fig.3(e)

\section{Tumut Precipitation - AM}

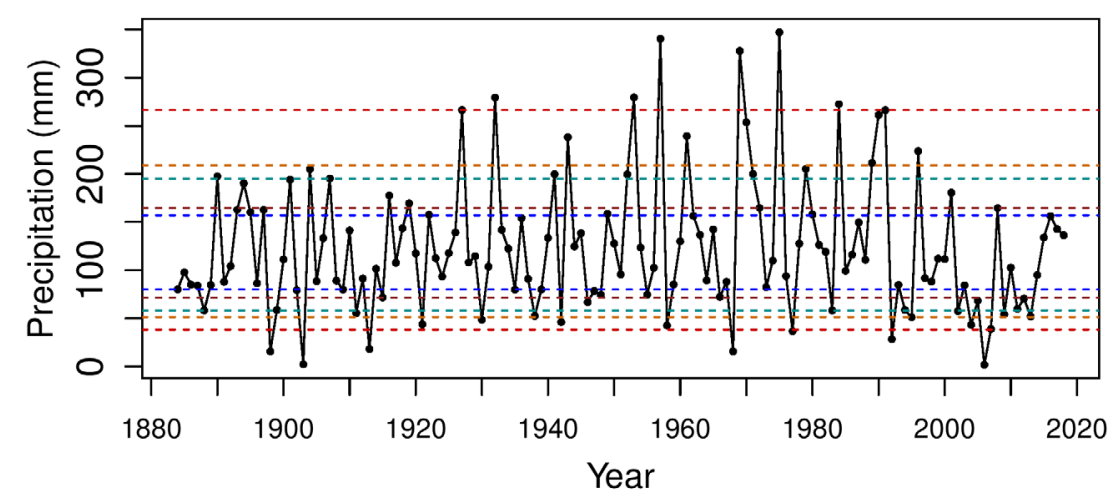

$190 \quad$ Fig.3(f)

192 All three locations, particularly Burrinjuck Dam and Blowering Dam, are exposed to

193 topographically influenced precipitation from mid-latitude wet season (JJAS) cold

194 frontal weather systems. For each location there has been no statistically significant

195 trend after bootstrapping and box plotting the precipitation into 27-year intervals, for

196 1965-1991 and 1992-2018. While their JJAS means appear to have decreased slightly

197 (not shown), no locations have observed statistically significant changes (Table 2). For

198 Tumut JJAS, precipitation was significantly more variable prior to 1965 (p-values =

1990.045 and 0.0984; Table 2). However, for all three locations, their mean late autumn

200 (April-May) precipitation shows a decline in both the mean and variance in the 27-year 
201 boxplots between 1965-1991 and 1992-2018 (Figs.4a, b, c). Statistically, there is a

202 highly significant decrease in both their means (p-values $<0.01$; Table 2), and their

203 variances ( $p$-values $\sim 0.05$; Table 2). It is noteworthy that while neither the mean nor

204 variance of Tumut April-May precipitation between 1884-1910 and 1992-2018 is

205 significant, their variances are similarly very low (Fig.4c-right panel), owing to the very

206 low rainfall that occurred during the Federation Drought (1895-1903).

\begin{tabular}{|c|c|c|c|c|c|c|c|c|c|c|c|c|}
\hline \multirow{3}{*}{ Catchment Location } & \multicolumn{4}{|c|}{ Precipitation } & \multicolumn{4}{|c|}{ Inflows (\% Volume) } & \multicolumn{4}{|c|}{ Murrumbidgee River level } \\
\hline & \multicolumn{2}{|c|}{ Apr-May } & \multicolumn{2}{|c|}{ JJAS } & \multicolumn{2}{|c|}{ Apr-May } & \multicolumn{2}{|c|}{ JJAS } & \multicolumn{2}{|c|}{ Apr-May } & \multicolumn{2}{|c|}{ JJAS } \\
\hline & mean & var. & mean & var. & mean & var. & mean & var. & mean & var. & mean & var. \\
\hline \multicolumn{13}{|l|}{ Blowering Dam } \\
\hline $\begin{array}{l}1965-1991 \text { vs } 1992-2018 \\
1976-1997 \text { vs } 1998-2019\end{array}$ & $0.007^{*}$ & $0.012^{*}$ & 0.202 & 0.978 & $0.0348^{*}$ & 0.301 & $0.0018^{*}$ & $0.0714^{*}$ & $0.0346^{*}$ & - & $0.0024^{*}$ & $0.087^{*}$ \\
\hline \multicolumn{13}{|l|}{ Burrinjuck Dam } \\
\hline $1938-1964$ vs $1965-1991$ & 0.772 & 0.644 & 0.846 & 0.424 & 0.145 & $0.093^{*}$ & $0.058^{*}$ & 0.352 & 0.357 & 0.268 & 0.094 & 0.605 \\
\hline $1938-1964$ vs $1992-2018$ & $0.0034^{*}$ & $0.0486^{*}$ & 0.905 & 0.818 & 0.566 & 0.391 & 0.104 & $0.0708^{*}$ & 0.476 & 0.544 & $0.0706^{*}$ & $0.051^{*}$ \\
\hline $1965-1991$ vs $1992-2018$ & $0.0024^{*}$ & $0.002^{*}$ & 0.761 & 0.635 & $0.0676^{*}$ & 0.517 & 0.003 & 0.328 & 0.148 & 0.606 & $0.0026^{*}$ & 0.115 \\
\hline \multicolumn{13}{|l|}{ Tumut } \\
\hline $1884-1910$ vs $1938-1964$ & 0.149 & 0.289 & 0.463 & $0.045^{*}$ & --------- & ------- & -------- & --------- & -------- & ----- & --------- & ------ \\
\hline $1938-1964$ vs $1965-1991$ & 0.528 & 0.278 & 0.308 & 0.984 & ------- & ------ & ------- & ------- & ------ & $-\cdots$ & ------- & ------ \\
\hline $1884-1910$ vs $1992-2018$ & 0.285 & 0.46 & 0.353 & $0.008^{*}$ & -------- & ------ & -------- & -------- & -------- & ---- & -------- & ------ \\
\hline $1965-1991$ vs $1992-2018$ & $0.0062^{*}$ & $0.0026^{*}$ & 0.227 & 0.505 & ---- & ------- & -------- & -------- & ---------- & ---- & ---------- & ------- \\
\hline \multicolumn{13}{|l|}{ Wagga Wagga } \\
\hline $1911-1937$ vs $1938-1964$ & ------ & ------ & --- & ---- & - & ----- & ------ & (- & - - - & ---- & 0.399 & 0.55 \\
\hline $1911-1937$ vs $1992-2018$ & ------ & ------- & 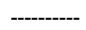 & ----- & ------- & --.-- & ------- & 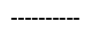 & -------- & --- & $0.0002^{*}$ & $0.013^{*}$ \\
\hline $1938-1964$ vs $1965-1991$ & ------ & ------ & -------' & ------ & --------- & ----- & ----- & ----- & --------- & ---- & 0.374 & 0.275 \\
\hline $1965-1991$ vs $1992-2018$ & ------ & ------ & 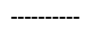 & ---- & $\ldots$ & $\ldots$ & 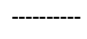 & & & -- & $0.0044^{*}$ & $0.095^{*}$ \\
\hline \multicolumn{13}{|l|}{ Hay } \\
\hline $1911-1937$ vs $1965-1991$ & -------- & ---- & --.-- & ----- & 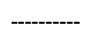 & - & ---- & - & ------ & - & 0.19 & 0.683 \\
\hline $1911-1937$ vs $1992-2018$ & ------- & -.--o-- & -.--o-- & -.--- & --------- & ----- & ------ & ------ & ------- & ---- & $0.0068^{*}$ & $0.001^{*}$ \\
\hline $1938-1964$ vs $1965-1991$ & ------- & ------- & 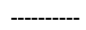 & ----- & 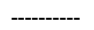 & --.-- & ------- & 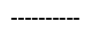 & ------- & --.-- & 0.309 & 0.332 \\
\hline $1965-1991$ vs $1992-2018$ & ------- & -------- & -------- & ------ & ------- & --.-- & --------- & 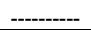 & ------- & ----- & 0.236 & $0.005^{*}$ \\
\hline
\end{tabular}

208 Table 2. P-Values from permutation testing differences in interval means and

209 variances for, April-May and JJAS precipitation Blowering Dam, Burrinjuck Dam, and

210 Tumut; inflows into Blowering Dam and Burrinjuck Dam; Murrumbidgee River heights

211 at Blowering Dam, Burrinjuck Dam, Wagga Wagga and Hay. Significant values $(\mathrm{P}<$

$2120.10)$ are italicized with an asterisk. Note that the $\mathrm{P}$-value for each variance test is

213 calculated after one sample has had bias correction in the mean.

215 There is an apparent decrease in the mean and variance of JJAS Murrumbidgee River

216 heights at Hay between the bootstrapped intervals 1938-1964 to 1965-1991 highlighted

217 by their low $\mathrm{p}$ values (Table 2; figure not shown), which corresponded to a change from

218 low to highly regulated river flow ${ }^{[10]}$. However, the apparent mean and variance

219 decrease is not statistically significant, whereas the variance between the 27-year 
bootstrapped intervals $1965-1991$ to $1992-2018$ is highly significant (p-value $\sim 0.005$;

221 Table 2). The mean river height in this period for Hay $(p=0.236$; Table 2$)$ is not statistically significant most likely due to snow melt starting to reach Hay in September.

223 Both Hay and Wagga Wagga river heights are significantly lower in both mean and 224 variance from 1911-1937 to 1992-2018 owing to a high rainfall period 1911-1937 compared to the period $1992-2018$ ( $\mathrm{p}$ values $=0.0068,0.001$, respectively for Hay; 0.0002, 0.013, respectively for Wagga Wagga). For Wagga Wagga the decrease in both the mean and variance from 1965-1991 to 1992-2018 is highly significant (p-values 0.0068 and 0.001 , respectively; Table 2). Importantly, the significant mean decrease at Wagga Wagga suggests that the cause is climate related with river water used for

230 irrigation not a major contributor since irrigation occurs downstream between Wagga

231 Wagga and Hay. There is no significant change in October-March precipitation mean or variance from 1965-1991 to 1992-2018 for the three catchment rainfall locations (pvalues not shown). catchment precipitation.

237 Bootstrapped 27-year intervals of mean (left panel) and variance (right panel) of April-
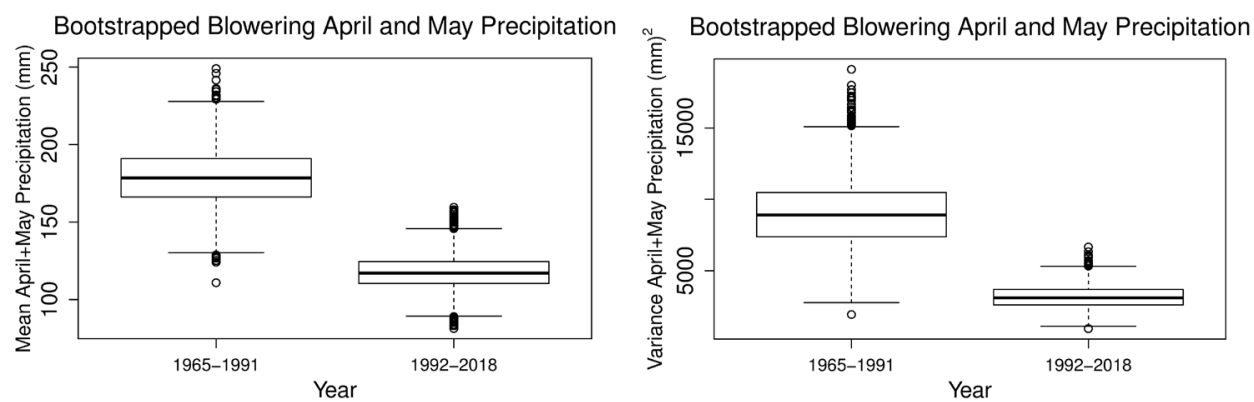

Fig. $4 \mathbf{a}$ 

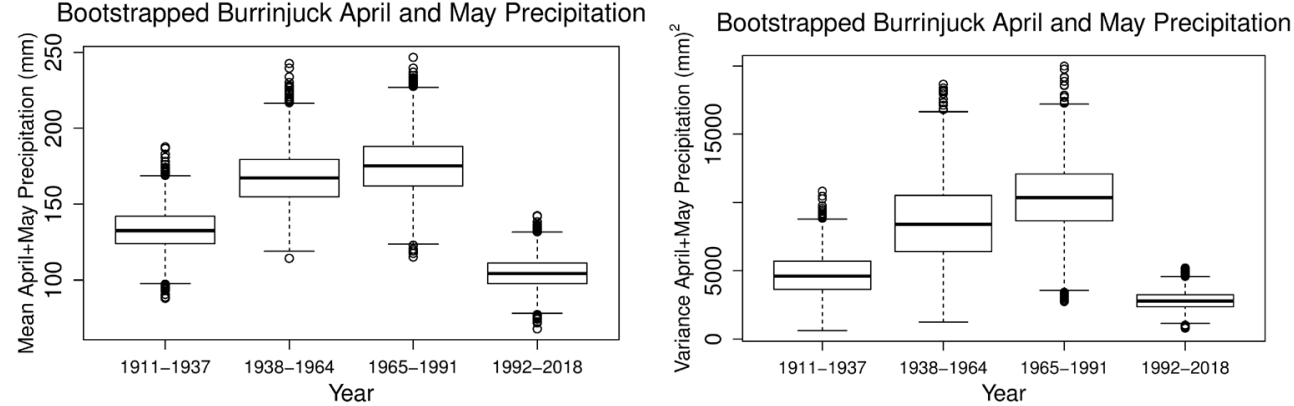
Fig. $4 \mathbf{b}$

Fig.4c
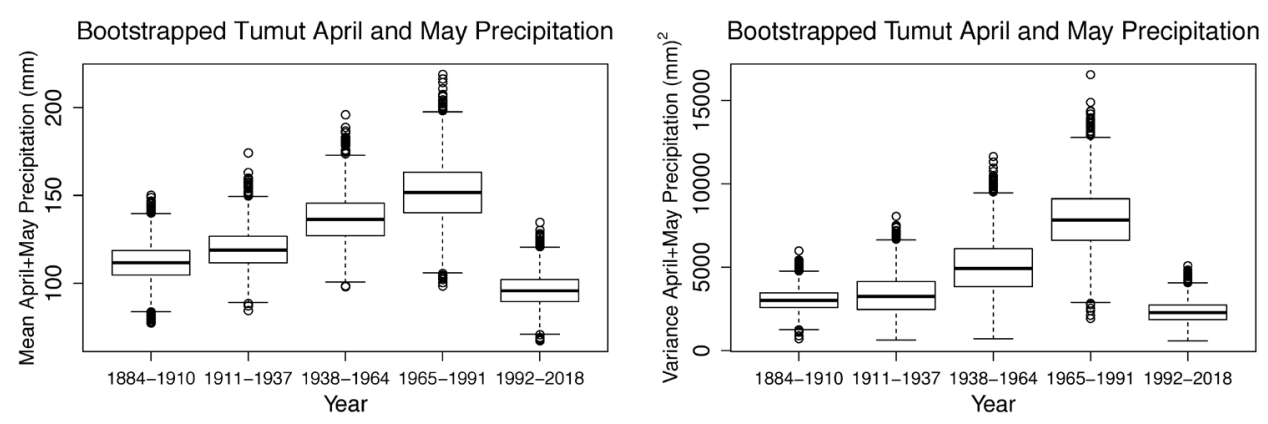

The mean JJA precipitation wavelets for Burrinjuck Dam, Blowering Dam, Tumut

and the mean JJA weekly Murrumbidgee River heights at Hay (Figs.5a-d), respectively,

exhibit a significant ENSO-like periodicity of approximately 2-7 years, which mostly

weakens in the three precipitation locations from the 1990s, and, in the case of the river

247 heights at Hay, disappears after the 1990s. A possible reason for the weakening ENSO-

248 like periodicity is that the nonlinear ENSO amplitude has weakened (less strong El

249 Niños) in response to global warming ${ }^{[14,15}$.

Fig. 5 Wavelets of JJAS precipitation and river height. JJAS wavelets and global power spectra of precipitation for, a Burrinjuck Dam, b Blowering Dam, c

254 Tumut; and d JJAS mean weekly Murrumbidgee river heights at Hay. Power significance is indicated by areas within thick black or red contours the $5 \%$ or $10 \%$ confidence levels, respectively. 

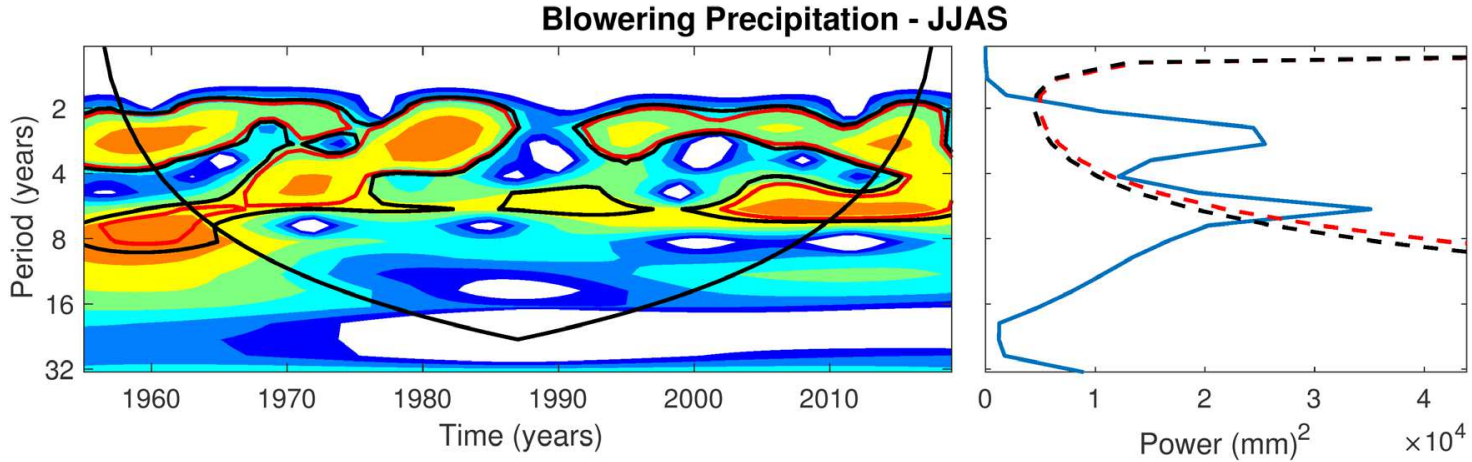

$258 \quad$ Fig.5a
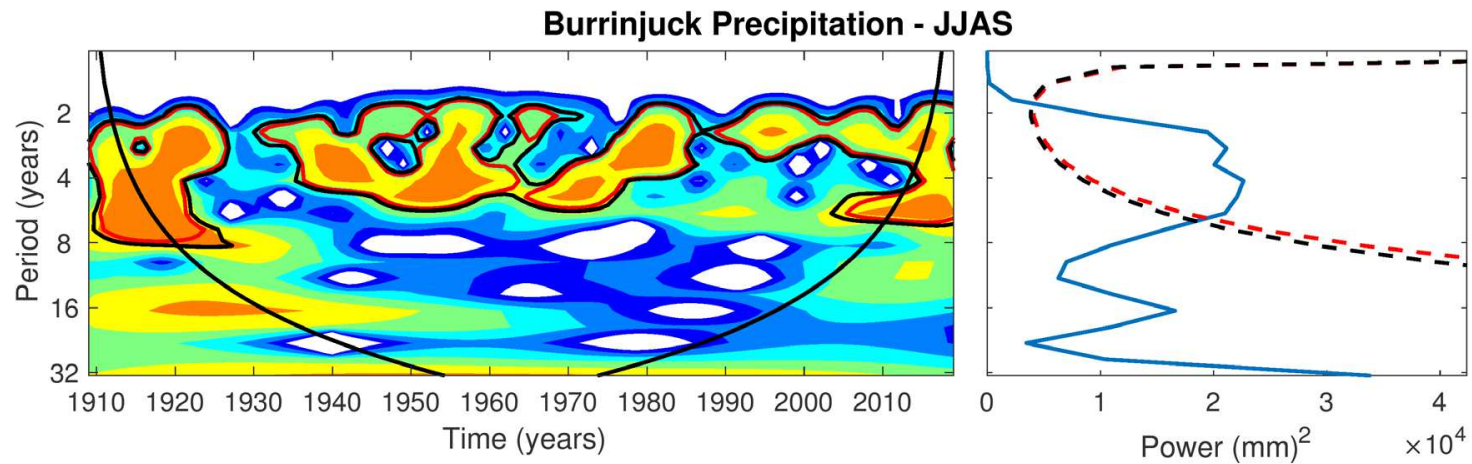

$260 \quad$ Fig. 5 b
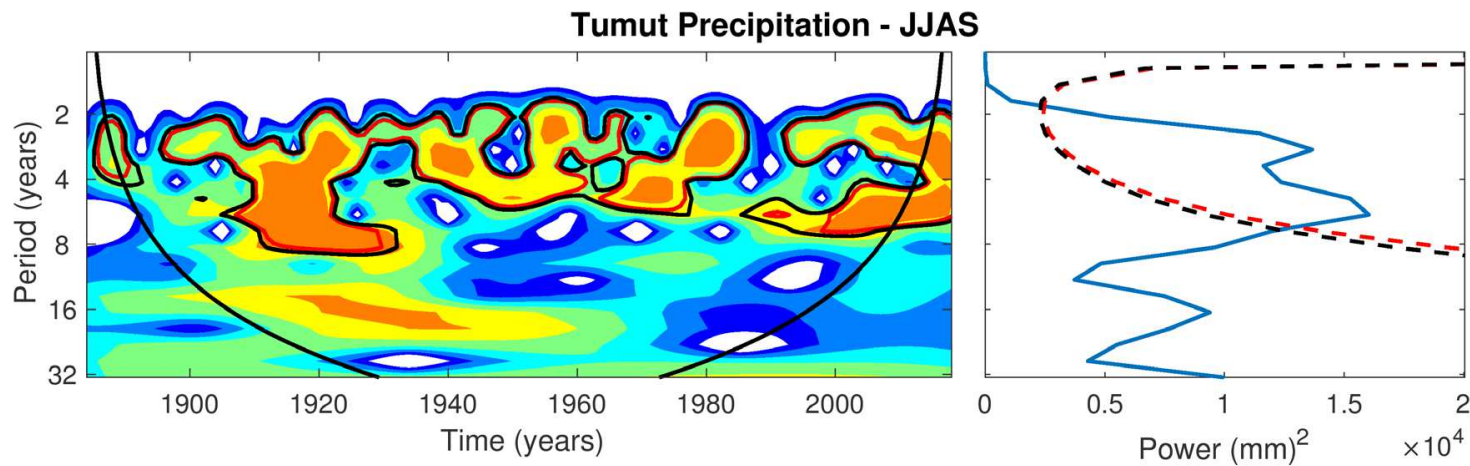

$262 \quad$ Fig.5c

Hay River Height - JJAS
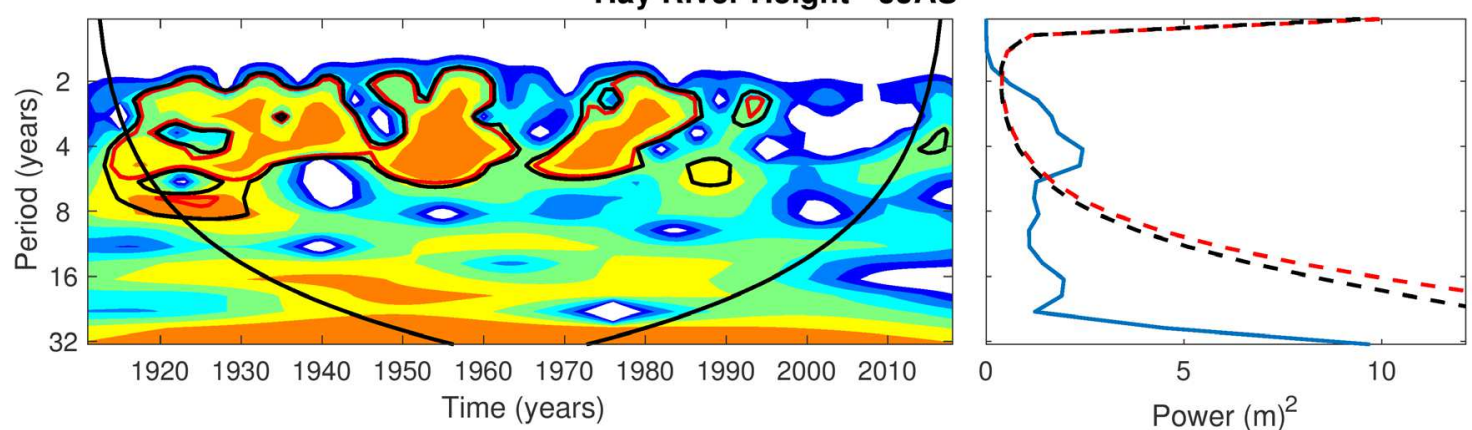

Fig.5d 
266

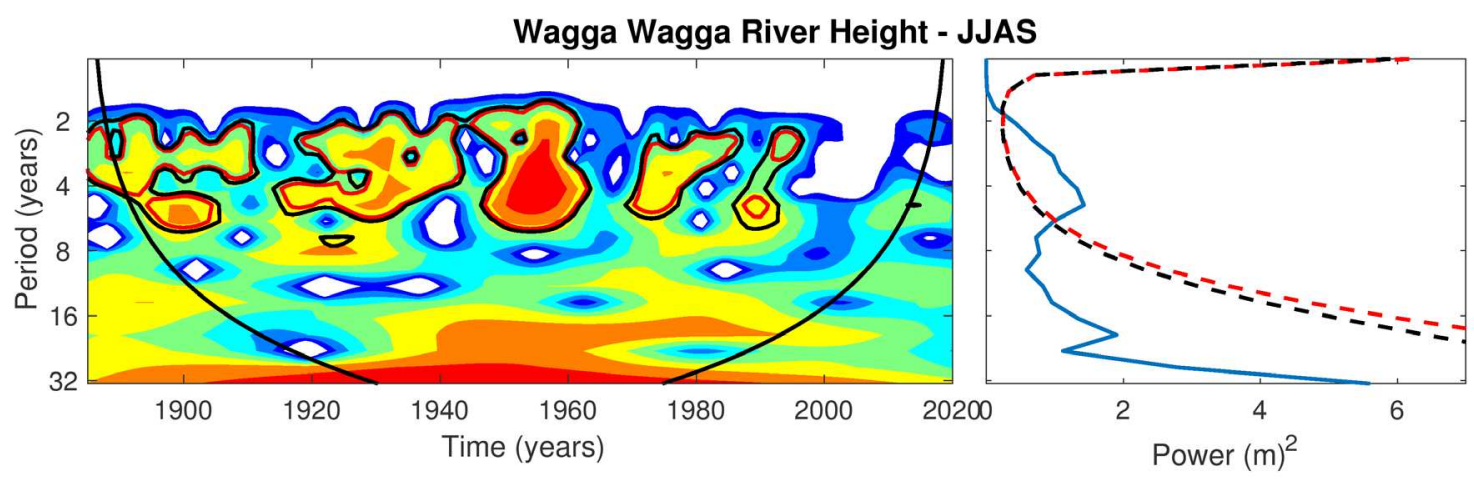

$267 \quad$ Fig. $5 \mathbf{e}$

268 There is clear periodicity of 2-7 years resembling the ENSO time scale at the three

catchment precipitation locations (Figs. 5a, b, c). However, the ENSO signal disappears from the late 1990s for the downstream river heights at Wagga Wagga and Hay (Figs. $5 d, \mathbf{e})$.

There is a clear increasing trend in JJAS mean TMax and TMin at both Burrinjuck

273 Dam and Cabramurra (located close to Blowering Dam), revealed by their 27-year interval boxplots (Figs.6a, b, c, d), and consistent with the known global warming signal since $1950{ }^{[16]}$ which has accelerated in the last 50 years ${ }^{[17,18]}$ and particularly since the mid-1990s in Australia ${ }^{[12]}$. This is confirmed by the very high levels of significance (all p-values are $<0.05$ ) for the difference in TMax and TMin means between the intervals 1965-1991 to 1992-2018 (Table 3).

Table $3 \quad$ P-values from permutation testing differences in JJAS mean maximum 284 (TMax) and mean minimum (TMin) temperature (0C) relative to 27-year bootstrapped intervals for Burrinjuck Dam and Cabramurra (nearby surrogate for Blowering Dam).

\begin{tabular}{|c|c|c|c|c|c|}
\hline \multirow{2}{*}{$\begin{array}{l}\text { 27-year } \\
\text { Bootstrapped } \\
\text { Interval }\end{array}$} & \multirow[t]{2}{*}{ Statistic } & \multicolumn{2}{|c|}{$\begin{array}{l}\text { JJAS Burrinjuck } \\
\text { Dam P-values }\end{array}$} & \multicolumn{2}{|c|}{$\begin{array}{l}\text { JJAS Cabramurra } \\
\text { P-values }\end{array}$} \\
\hline & & TMax & TMin & TMax & TMin \\
\hline \multirow{2}{*}{$\begin{array}{l}1965-1991 \text { vs } \\
1992-2018\end{array}$} & Mean & $0^{*}$ & $0.0452 *$ & $0 *$ & $0.002 *$ \\
\hline & Variance & 0.849 & 0.926 & 0.613 & 0.647 \\
\hline
\end{tabular}
Significant values $(\mathrm{P}<0.05)$ are italicized with an asterisk. 
290 a Bootstrapped 27-year interval Burrinjuck JJA mean TMax $\left({ }^{0} \mathrm{C}\right)$, b

291 bootstrapped 27-year interval Cabramurra JJA mean TMax $\left({ }^{\circ} \mathrm{C}\right)$, c bootstrapped 27-year

292 interval Burrinjuck Dam JJA mean TMin $\left({ }^{\circ} \mathrm{C}\right)$, and $\mathbf{d}$ bootstrapped 27-year interval

293 Cabramurra JJA mean TMin $\left({ }^{0} \mathrm{C}\right)$.

295 Fig.6a

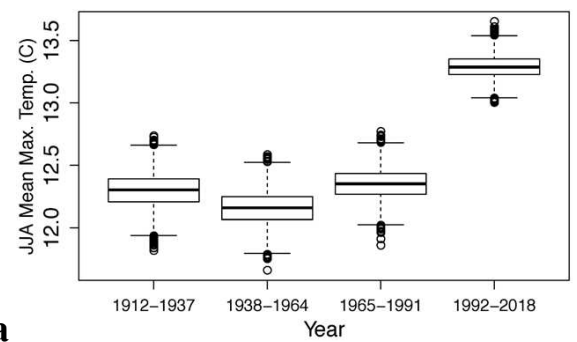

296

Fig.6c

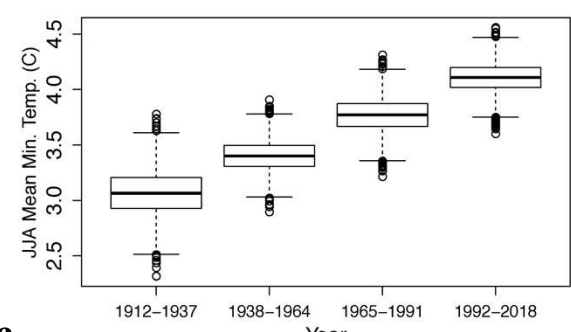

Fig.6d

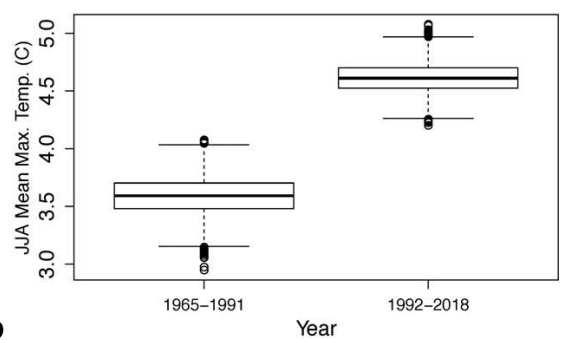

Fig.6b

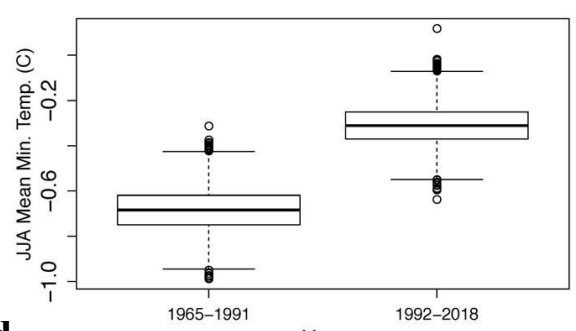

Year

298 Cabramurra (altitude $1482 \mathrm{~m}$ ) shows a highly significant increase in TMin between the

299 two bootstrapped intervals in contrast to a non-significant increase at Burrinjuck Dam

300 (altitude $390 \mathrm{~m}$ ). With such a large difference in altitude between the two locations, it is

301 possible that other factors may be involved, including local differences in

302 meteorological variables such as wind speed/wind direction and/or cloud cover.

3. Discussion 
The JJAS river heights at Hay (Fig.2a) have clearly reduced variability over the 27year period 1965-1991 compared with 1992-2018 ( $p$-value $=0.005$, Table 2). Despite

307 the apparent decrease in the mean and variance of JJAS Murrumbidgee River heights at

308 Hay from the $1960 \mathrm{~s}$, as shown by the low p values $(0.309,0.332)$, respectively, for the

309 27-year intervals 1938-1964 to 1965-1991 (Table 2), the decrease is not statistically

310 significant. However, the decrease is consistent with the suggestion that a change point

311 occurred from the late 1950s between unregulated to regulated flow at Hay ${ }^{[10]}$.

312 While the mean JJAS precipitation of the three catchment locations of Burrinjuck

313 Dam, Blowering Dam and Tumut indicate a slight decrease in percentile extremes from

314 the 1990s, with 2016 (due to September) only above the 95th percentile (Fig.3), they

315 exhibit no significant change in mean or variance based on the bootstrapped intervals

316 JJAS 1964-1991 to 1992-2018. Consequently, the question arises of why the significant

317 decrease in mean and variance of the JJAS Murrumbidgee River height at Wagga

318 Wagga and in variance at Hay does not match a similar significant decrease in mean or

319 variance of JJAS catchment rainfall. A rainfall decline in recent decades was found to

320 be most pronounced in late autumn ${ }^{[19,20]}$ and that without sufficient autumn rainfall to

321 moisten catchments in southern Australia, follow-up rainfall in winter cannot be

322 efficiently converted to run-off and catchment inflows ${ }^{[21]}$. There have been statistically

323 significant decreases in April-May mean precipitation at the catchment locations of

324 Blowering Dam, Burrinjuck Dam and Tumut from 1964-1991 to 1992-2018 and also for

325 the mean inflows to the two Dams (Table 2). Furthermore, as a result of the Millennium

326 Drought (1997-2009), modelling experiments indicate that, starting from very dry

327 conditions, the run-off response to rainfall only will return to the normal pre-drought

328 conditions after about 10-20 years of average rainfall ${ }^{[22]}$. Therefore, the significant

329 decrease in variance of Murrumbidgee River heights at Hay and in mean and variance at 
330 Wagga Wagga, is most likely due to the April-May reduced dam inflows and

331 precipitation, and from average JJAS catchment precipitation since 1991. Any role

332 played by water extraction for irrigation between Wagga Wagga and Hay, where

333 irrigation is concentrated, is likely to be small owing to the highly significant mean river

334 height reduction at Wagga Wagga which is upstream from Hay. In a different southern

335 MDB catchment study of the Millennium Drought 1997-2000, factors for a

336 disproportionate reduction in rainfall run-off were reduced mean annual rainfall, less

337 interannual variability of rainfall, changed seasonality of rainfall and lastly increased

338 potential evaporation ${ }^{[23]}$. However, the last two factors mentioned have since become

339 well established in the last decade with reference to the work in this study. It was

340 suggested that a rainfall reduction alone does not explain the observed inflow reduction

341 trend ${ }^{[24]}$. Even after a major rain event, the soils are so dry that they absorb more water

342 than before the rain event, and less reaches the dams and rivers than on a wet

343 catchment. In the last three decades it is unknown what the effect on run-off into dams

344 and the Murrumbidgee river has been in JJAS from major rain events because, apart

345 from August-September 2016, there have been no major catchment inflows since 1991

346 (Figs. 2c, d). In June and July 1991 there was a series of rain-producing cut-off low

347 pressure systems over inland NSW and the adjacent coast influencing the catchment,

348 interspersed with persistent, precipitation-producing frontal systems embedded in the

349 westerly airflow during July and August. Rain producing inland cut-off low pressure

350 systems over southeast Australia are the main influence on enhancing JJAS rainfall

351 totals ${ }^{[7]}$.

352 Decreased JJAS rainfall in continental southeast Australia has been evident for at

353 least the last two decades, as anticipated by climate scientists. The naturally periodic La

354 Niña phenomenon provided spring and summer rainfall during much of 2010 to 2012, 
which ended the Millennium Drought (1997-2009). The only other recent widespread significant rainfall in southeast continental Australia was in August-September 2016 due to a negative phase of the Indian Ocean Dipole (IOD). A negative IOD phase typically is associated with wetter than normal spring conditions for southeast Australia $[6,7]$.

360 The MDB plan, introduced from $2013^{[25]}$ provided, for the first time, regulated 361 allocations to environmental flows for ecosystem sustainability of rivers in southeast 362 Australia such as the Murrumbidgee. However, the plan requires that each year on 1 363 July a fixed amount of water is locked in for future consumption, split three ways with

364 the highest priority for human consumption and irrigation for permanent crops (e.g.,

365 fruit trees and nuts). The remaining allocations are split between non-permanent crops

366 (e.g., cotton, rice) and environmental flow. A problem is that the forecast inflows upon

367 which the allocations are based are the minimum inflows experienced in the 120 years 368 up to the end of the 20th century. However, as shown, even lower inflows have been 369 experienced in the past two decades. It is not surprising that there is a significant 370 decrease in the JJAS variance of the Murrumbidgee River height at Hay ( $p$-value = 371 0.005) and both the JJAS mean and variance at Wagga Wagga from the periods 19651991 to $1992-2018$ (mean $p$-value $=0.0044$, variance $p$-value $=0.095$; Table 2 ) since this period corresponds with the significantly reduced mean April-May catchment

374 precipitation and mean April-May dam inflows. The fact that there has been no 375 significant change in the mean Murrumbidgee River height since 1991 is an indication 376 that there has been a lack of major April-September rain events. The lack of significant 377 catchment rainfall events from April to September is the reason for the reduction in the 378 mean and variance of river heights at Wagga Wagga. Floods in April-May are rare 379 along the Murrumbidgee River and the six years since 1874 in which April-May floods 
occurred at Hay prior to 1991 (Table 1c), were dominated by precipitation that occurred as a result of mid-latitude interaction with either tropical or subtropical moisture,

whereas the last flood that occurred in March 2012, was the result of a rain-producing tropical low pressure system over central Australia. Moreover, given the significant decline in April-May, Murrumbidgee catchment rainfall, JJAS run-off into the dams and Murrumbidgee river height at Wagga Wagga since 1991, the implication for water allocations of irrigated agriculture downstream from Wagga Wagga and for flood plain environmental flows required for sustainable wetlands downstream from Hay, will continue to be a problem.

\section{Conclusions}

391 Both the mean and variability of JJAS river height data at Wagga Wagga and the

392 variability of JJAS river height data at Hay on the Murrumbidgee River in the

393 MDB have decreased significantly since the early 1990s, owing to one only July

394 minor flood level exceedance at Wagga since 1995 and one only September flood

395 level exceedance in 2016. In sharp contrast, the flood level at both Hay and

396 Wagga Wagga was exceeded every few years in JJAS from 1874 to the early

397 1990s. There has been no new regulatory infrastructure built upstream from Hay

398 since the 1960s. Bootstrapped data box plots for 27-year periods covering JJAS

399 months exhibit no statistically significant decline in the mean catchment rainfall at

400 locations including Burrinjuck Dam, Blowering Dam and Tumut for the period

401 1992-2018, to match the statistically significant lower mean and variability in

402 river heights at Wagga Wagga or the variability further downstream at Hay. Water

403 extraction for irrigation is unlikely to be a major cause between Wagga Wagga

404 and Hay because the river height had already decreased significantly at Wagga 
Wagga. However, there is a highly significant decline in late autumn (April-May)

406 mean and variance of catchment rainfall between the periods 1965-1991 and

407 1992-2018. Insufficient late autumn moistening of the dams' catchment areas

408 reduces run-off during JJAS months even when the mean JJAS rainfall has not

409 declined significantly. A further contributing factor is likely to be the observed

410 mean temperature increase during April-September, thereby increasing

411 evapotranspiration, and reducing run-off into rivers and dams. The contributions

412 of decreased April-May rainfall, decreased April-May and JJAS dam inflows, and

413 increased mean temperatures, which represents the accelerated global warming

414 signal since the 1990s, all reduced catchment area run-off. Future work therefore

415 is planned to address the high priority of searching for attributes, to assist in

416 identifying and understanding the role of the key meteorological drivers,

417 especially those related to the April-May decrease in catchment rainfall.

418 Regardless of the mandated environmental flows in the last decade and the

419 annually determined sustainable extraction limits on irrigation, water availability from

420 the Murrumbidgee River at Wagga Wagga and Hay over recent decades continues to be

421 affected by changes in catchment rainfall and run-off. In this study the decreased river

422 heights at Wagga Wagga and Hay in the 27-year period, 1992-2018, occurred as a result

423 of a change in seasonality of rainfall and increase in potential evaporation during the

424 current accelerated period of global warming as described above, suggesting the need

425 for a new review of water availability and sustainability in the Murrumbidgee River

426 system and also of other river systems in the southern MDB.

\section{Methods}

The available data sets were Murrumbidgee River heights at Hay in the southern 
$430 \mathrm{MDB}$, monthly precipitation, and maximum and minimum screen temperatures at four

431 stations at Blowering Dam, Burrinjuck Dam, Tumut and Cabramurra. The aims of the

432 Methodology were to identify trends in the data sets and to use wavelet analysis to

433 identify possible climate drivers of the trends.

434

435 Trend Analysis

436 The time series data were first plotted with their percentiles to obtain an

437 overview of any trends which might be present in the data. Each data set was grouped

438 into two equal 27-year periods, by taking account of the accelerated global warming

439 signal from the mid-1990s and the archived length of each variable. Hence, the ending

440 period was 1992-2018, and bootstrap resampling was applied with 5000 resamples. Box

441 plots of the mean and variance of the bootstrapped intervals were created which provides

442 a deeper understanding of any trends which might be present in the data. Permutation

443 testing was applied with replacement to test for statistical significance in any apparent

444 changes between two 27-year periods.

445

446 Wavelet Analysis

447 Wavelet analysis ${ }^{[26,27]}$ was applied to each time series to detect potential climate

448 drivers such as the El-Niño Southern Oscillation. This approach provides both the local

449 wavelet power spectrum (e.g., Fig.6a, left panel) and the global power spectrum (e.g.,

450 Fig.6a, right panel). The local wavelet power spectrum shows how the influence of

451 climate drivers changes over time, while the global power spectrum provides an

452 overview of which drivers are dominant in the time series. In this study, we used the

453 Morlet wavelet as the mother wavelet.

454

455

6. Data availability 
457 the Australian Bureau of Meteorology. The digitized weekly river height data are

458 available at: - https://doi.org/10.5281/zenodo.3779490

459

460 Acknowledgements: The authors acknowledge the University of Technology Sydney

461 for supporting this research. JH acknowledges support from the Australian

462 Government Research Training Program Scholarship.

463

464 Author contributions: M. Speer conceived much of the study and wrote the first draft; manuscript; J. Hartigan provided many of the figures and assisted in reviewing the manuscript; S. MacNamara assisted in reviewing the manuscript.

Competing interests: The authors declare no competing interests (neither financial nor of other forms).

\section{References}

473 1. Holland, J.E., Luck, G.W. \& Finlayson, C.M. Threats to food production and water quality in the Murray-Darling Basin of Australia. Ecosyst. Serv. 12, 55-70 (2015).

476

477 2. United States Geological Survey. California's Central Valley facts. https://ca.water.usgs.gov/projects/central-valley/about-central-valley.html 
$4803 . \quad$ Murphy, B.F. \& Timbal, B. A review of recent climate variability and climate change in southeastern Australia. Int J. Climatol. 28, 859-879 (2008). DOI: $10.1002 /$ joc. 1627

483

484 4. Bureau of Meteorology. 2019b. Special Climate Statement 70: drought conditions in eastern Australia and impact on water resources in the MurrayDarling Basin. Australian Bureau of Meteorology, 9 April 2019. http://www.bom.gov.au/climate/current/statements/scs70.pdf

488

5. Post, D.A. et al. Decrease in southeastern Australian water availability linked to 492

6. Ummenhofer, C.C. et al. 'What causes southeast Australia's worst droughts?' Geophys. Res. Lett. 36, no. 4, pp. 1-5 (2009).

7. Risbey, J.S., Pook, M.J., McIntosh, P.C., Wheeler, M.C. \& Hendon, H.H. On the remote drivers of rainfall variability in Australia. Mon. Wea. Rev. 137, 32333253 (2009).

499

$500 \quad 8$ Kingsford, R.T. \& Thomas, R.F. Destruction of wetlands and waterbird populations by dams and irrigation on the Murrumbidgee River in arid Australia. Environmental Management 34, 383-396 (2004) DOI: 10.1007/s00267-0040250-3 
505 9. Page, K., Reid, A., Frazier, P. \& Mount, N. The Effect of Altered Flow Regime on the Frequency and Duration of Bankfull Discharge: Murrumbidgee River, Australia. River Res. Applic. 21, 567-578 (2005) DOI: 10.1002/rra.828

508

10. Ren, S. \& Kingsford, R.T. Modelling impacts of regulation on flows to the Lowbidgee floodplain of the Murrumbidgee River, Australia. J. Hydrology 519, 1660-1667 (2014) DOI: 10.1016/j.jhydrol.2014.09.003

513 11. Speer, M.S. Digitisation of weekly Murrumbidgee river heights at Hay south eastern Australia 1873-2017. Geosciences Data Journal 5, June 2018, 9-13. https://doi.org/10.1002/gdj3.54

12. McBride, J.L. \& Nicholls, N. Seasonal Relationships between Australian 24pp. https://bom.gov.au/state-of-the-climate/ | csiro.au/state-of-the-climate

524 14. Ham, Y.-G. A reduction in the asymmetry of ENSO amplitude due to global warming: The role of atmospheric feedback. Geophys. Res. Lett. 44, 8576-8584

15. Kohyama, T., Hartmann, D. L., \& Battisti, D. S. Weakening of nonlinear ENSO under global warming. Geophys. Res. Lett. 45 (2018) https://doi.org/10.1029/2018GL079085 
532 16. Climate Change 2014: Synthesis Report. Contribution of Working Groups I, II and III to the Fifth Assessment Report of the Intergovernmental Panel on Climate Change. Pachauri et al. hdl:10013/epic.45156

17. Morice, C.P., Kennedy, J.J., Rayner, N.A. \& Jones, P.D. Quantifying uncertainties in global and regional temperature change using an ensemble of observational estimates: the HadCRUT4 dataset. J. Geophys. Res., 117, D08101 (2012) doi:10.1029/2011JD017187

18. NOAA National Centers for Environmental Information, State of the Climate: Global Climate Report for 2019, published online January 2020, retrieved on February 3, 2021 from https:/www.ncdc.noaa.gov/sotc/global/201913/supplemental/page-3

19. Cai, W. \& Cowan, T. Southeast Australia Autumn Rainfall Reduction: A Climate-Change-Induced Poleward Shift of Ocean-Atmosphere Circulation. $J$. Clim. 26, 189-205 (2013) https://doi.org/10.1175/JCLI-D-12-00035.1

20. Lin, Z., Li, Y., Liu, Y. \& Hu, A. The Decadal Reduction of Southeastern

555 21. Cai, W. \& Cowan, T. Dynamics of late autumn rainfall reduction 
22. Chiew, F.H.S. et al. Observed hydrologic non-stationarity in far south-eastern Australia: implications for modelling and prediction. Stoch. Environ. Res. Risk Assess. 28, 3-15 (2014) DOI 10: 1007/s00477-013-0755-5

562

563

23. Potter, N.J. \& Chiew, F.H.S. An investigation into changes in climate characteristics causing the recent very low runoff in the southern MurrayDarling Basin using rainfall-runoff models. J. Hydrol. 381, 52-64 (2010) http://dx.doi.org/10.1029/2010WR010333

567

24. Sharma, A., Wasko, C., \& Lettenmaier, D.P. If precipitation extremes are increasing, why aren't floods? Water Res. Res. (2018) 54, 8545-8551. https://doi.org/10.1029/2018WR023749

25. MDBA. Water Act 2007 - Basin Plan 2012. Prepared by the Murray-Darling Basin Authority (2012) Available at: http://www.comlaw.gov.au/Details/F2012L02240

26. Lau, K.M. \& Weng, H. Climate Signal Detection Using Wavelet Transform: How to Make a Time Series Sing. Bull. Amer. Meteor. Soc. 76, 2391-2402

27. Torrence, C. \& Compo, G.P. A Practical Guide to Wavelet Analysis. Bull. Amer. (1995) DOI: 10.1175/1520-0477(1995)076<2391:CSDUWT>2.0.CO;2 


\section{Table Legends}

Table 1a Table showing wet season (JJAS) monthly maximum weekly Murrumbidgee River heights at Hay (southern MDB) that exceed/equal flood level $(6.7 \mathrm{~m})$, and seasonal count, in the 125 years $1874-2018$

Table showing spring (SON) weekly maximum Murrumbidgee river heights at Hay (southern MDB) that exceed flood level (6.7 m), and seasonal count, in the 125 years 1874-2018. Also included is the strength of the ENSO signal as determined by the Australian Bureau of Meteorology (http://www.bom.gov.au/climate/enso/lnlist/index.shtml ). Note the neutral Murrumbidgee River heights at Hay (southern MDB) that exceed flood level $(6.7 \mathrm{~m})$, and seasonal count in the 126 years 1874-2019.

601 (http://www.bom.gov.gov.au/climate/enso/lnlist/index.shtml ). Note the neutral 603

Table 2 P-values from permutation testing differences in interval means and variances for, April-May and JJAS precipitation for Blowering Dam, Burrinjuck Dam, and Tumut; inflows into Blowering Dam and Burrinjuck Dam;

612 Figure Legends

613

614 Figure 1 The Murrumbidgee River and catchment area. 
$615 \mathrm{M}=$ Murrumbidgee Irrigation Area (hatched black), $\mathrm{C}=$ Colleambally Irrigation Area 616 (hatched black). Snowy Mountains Hydroelectric Scheme (hatched blue). The inset identifies the catchment location in southeast Australia.

618 inflows at Blowering Dam and Burrinjuck Dam.

621

622

623

624

625

626

627

628

629

630

631

632

633

634

635

636

637

638

639

640

641

642

643

644

645

646

647

a Murrumbidgee river heights (m) at the Hay town gauge and Hay PID for (April-September) 1874 to 2019. There are concurrent readings at the two locations from 1968 to 1982. The first April height every 5 years is indicated. The river flood level is marked (dashed black line) at $6.7 \mathrm{~m}$. Six maximum April-September weekly river heights exceeding the flood level of $6.7 \mathrm{~m}$, including the most recent (31 July 1991), are designated, b Murrumbidgee river heights at Wagga Wagga (April to September) 1885-2019. The minor flood level is marked (dashed black line) at $7.3 \mathrm{~m}$. The most recent minor flood levels reached since 1991 are marked, c Annual volume storage (\%) for Blowering Dam indicating precipitation inflows from 1975-2019, d Annual volume storage (\%) for Burrinjuck Dam indicating precipitation inflows from 1913-2019.

\section{Figure 3 Precipitation time series in the Murrumbidgee River catchment} area.

JJAS precipitation at, a Burrinjuck Dam from 1910-2019, b Blowering Dam from 1955-2019 and c Tumut from 1883-2019; April-May precipitation at, d Burrinjuck Dam from 1910-2019, e Blowering Dam from 1955-2019 and, f Tumut from 1883-2019. Dashed lines indicate percentiles 5th and 95th (red); 10th and 90th (orange); 15th and 85th (light blue); 20th and 80th (brown); and 25 th and 75 th (dark blue).

\section{Figure 4 Boxwhisker plots representing mean and variance of April-May} Murrumbidgee catchment precipitation.

Bootstrapped 27-year intervals of mean (left panel) and variance (right panel) of April-May precipitation for, a Blowering Dam, b Burrinjuck Dam, c Tumut. 
648 Figure 5 Wavelets of JJAS precipitation and river height.

649

650

651

652

653

654

655

656

657

658

659

660

JJAS wavelets and global power spectra of precipitation for, a Burrinjuck Dam, b Blowering Dam, c Tumut; and d JJAS mean weekly Murrumbidgee river heights at Hay. Power significance is indicated by areas within thick black or red contours the $5 \%$ or $10 \%$ confidence levels, respectively.

Figure 6 Box plots of mean temperature in the Murrumbidgee River catchment.

a Bootstrapped 27-year interval Burrinjuck JJA mean TMax $\left({ }^{0} \mathrm{C}\right)$, b bootstrapped 27-year interval Cabramurra JJA mean TMax $\left({ }^{0} \mathrm{C}\right)$, c bootstrapped 27-year interval Burrinjuck Dam JJA mean TMin $\left({ }^{0} \mathrm{C}\right)$, and $\mathbf{d}$ bootstrapped 27year interval Cabramurra JJA mean TMin $\left({ }^{0} \mathrm{C}\right)$. 


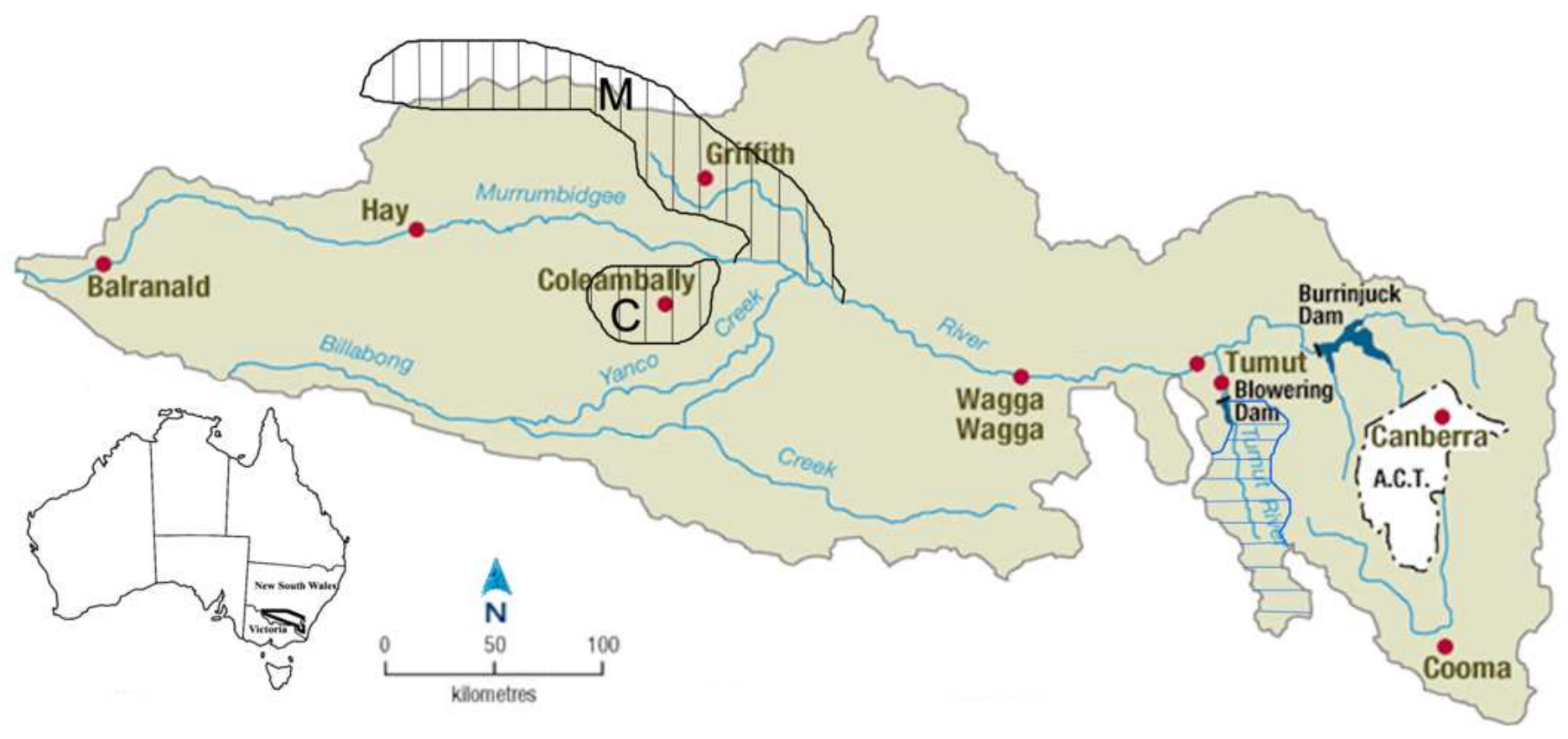

Figure 1

The Murrumbidgee River and catchment area. $M=$ Murrumbidgee Irrigation Area (hatched black), $C=$ Colleambally Irrigation Area (hatched black). Snowy Mountains Hydroelectric Scheme (hatched blue). The inset identifies the catchment location in southeast Australia. 

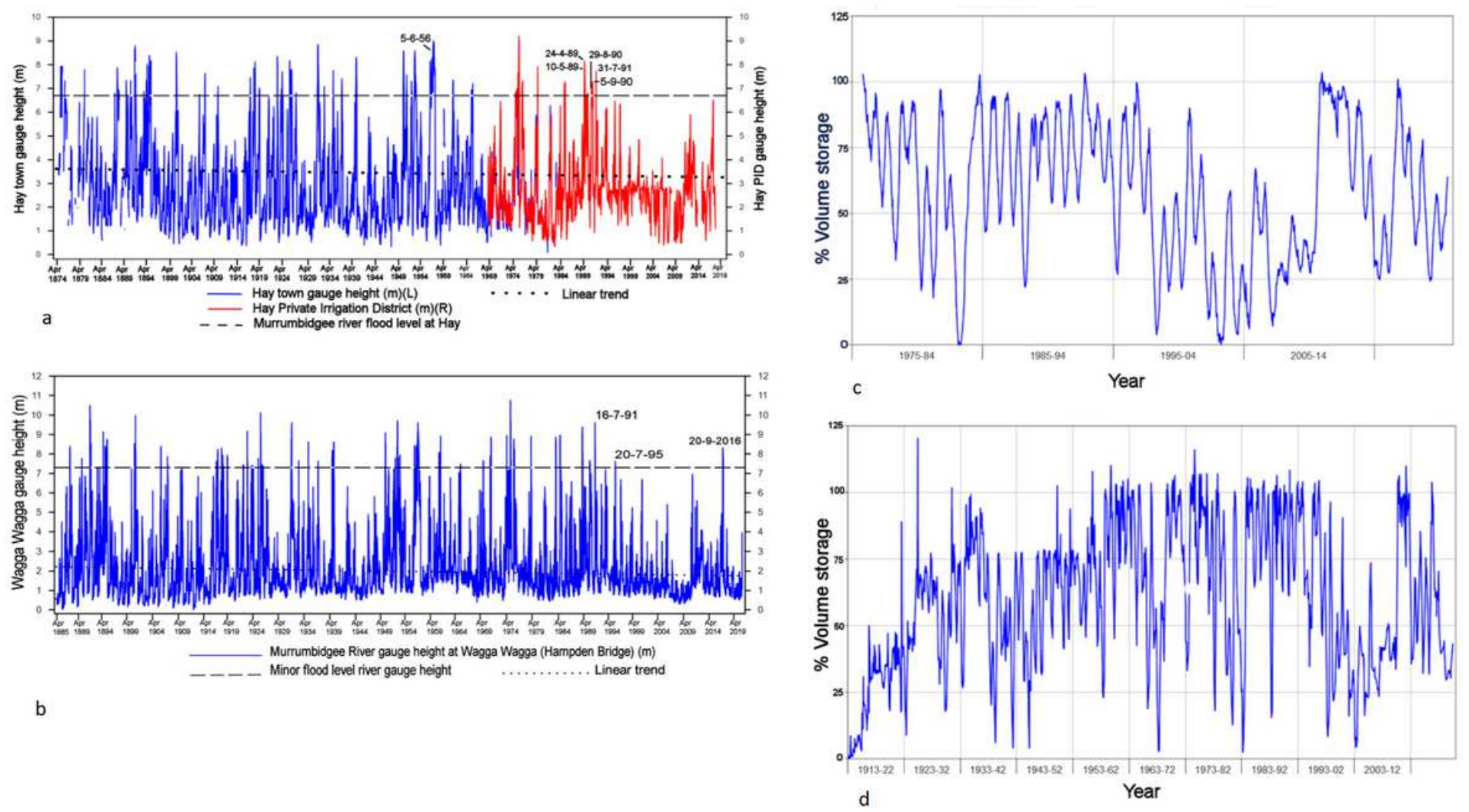

Figure 2

a. Murrumbidgee river heights $(\mathrm{m})$ at the Hay town gauge and Hay PID for (April-September) 1874 to 2019. There are concurrent readings at the two locations from 1968 to 1982. The first April height every 5 years is indicated. The river flood level is marked (dashed black line) at $6.7 \mathrm{~m}$. Six maximum AprilSeptember weekly river heights exceeding the flood level of $6.7 \mathrm{~m}$, including the most recent (31 July 1991), are designated. b. Murrumbidgee river heights at Wagga Wagga (April to September) 1885-2019. The minor flood level is marked (dashed black line) at $7.3 \mathrm{~m}$. The most recent minor flood levels reached since 1991 are marked. c. Annual volume storage (\%) for Blowering Dam indicating precipitation inflows from 1975-2019. d. Annual volume storage (\%) for Burrinjuck Dam indicating precipitation inflows from 1913-2019. 

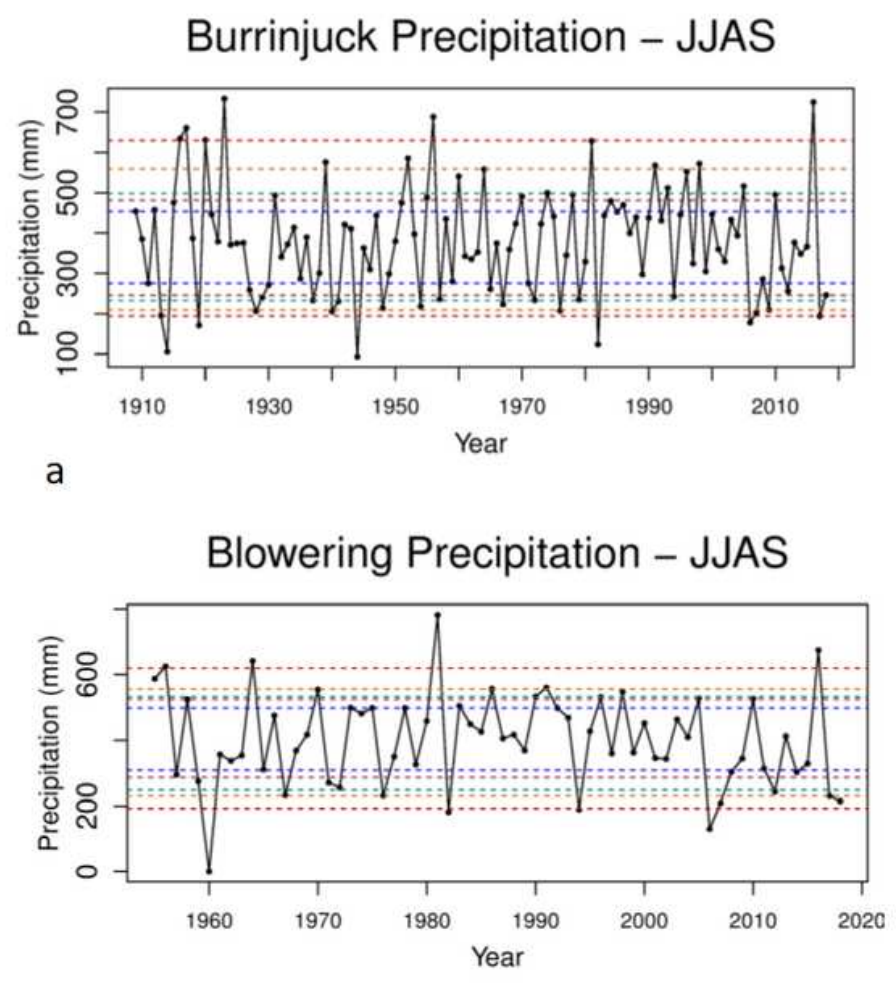

b

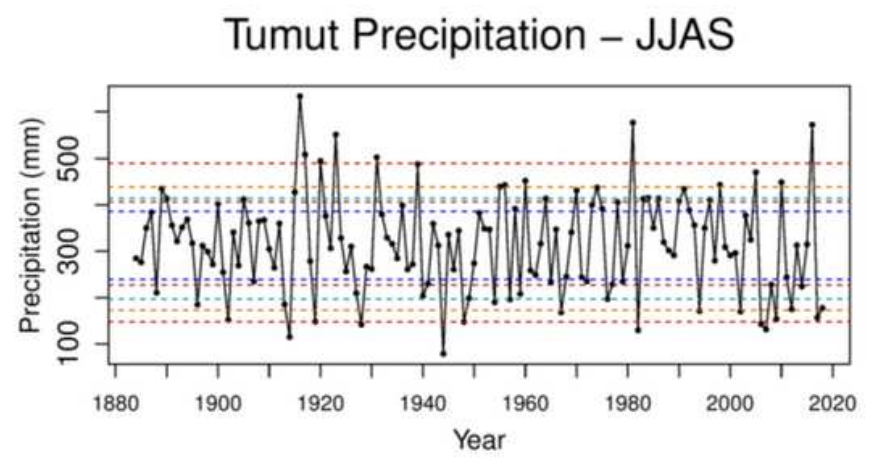

c

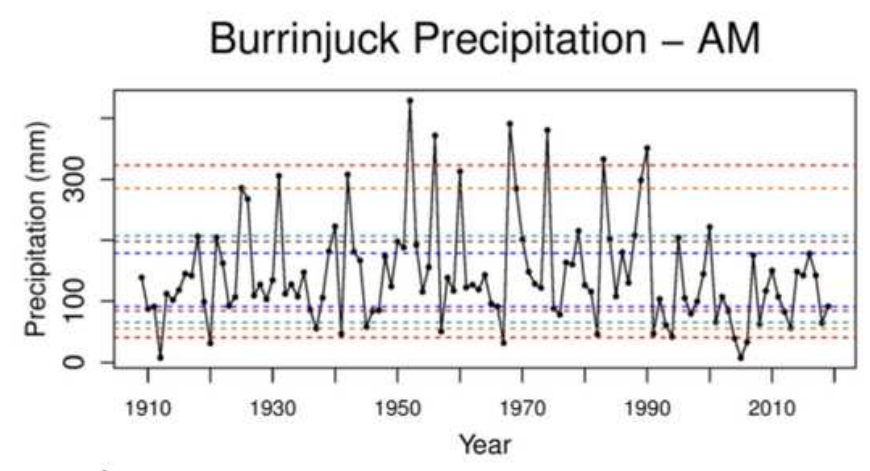

d

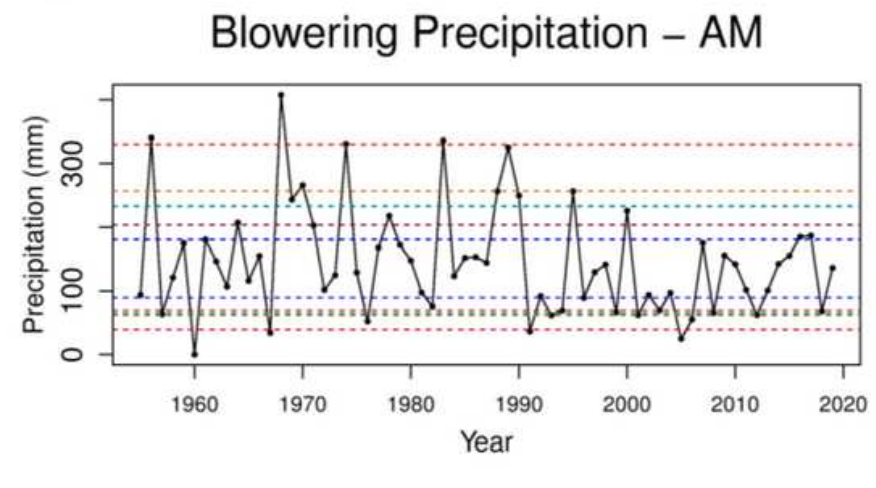

$\mathrm{e}$

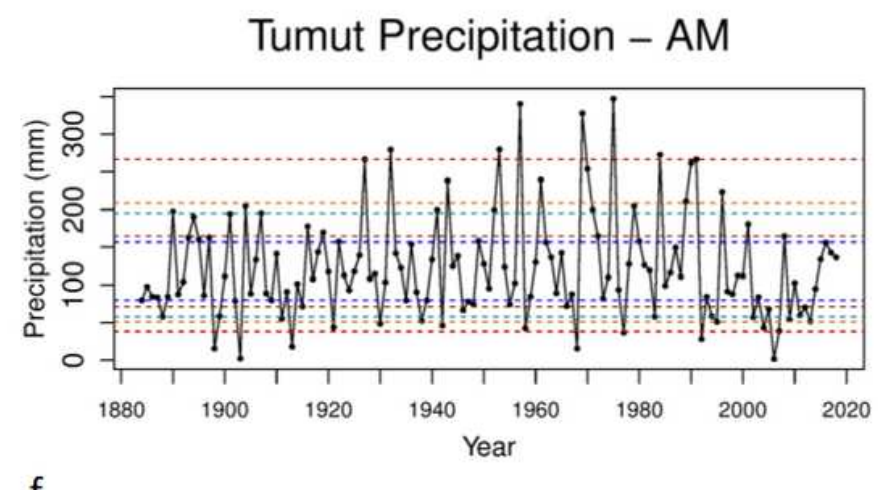

\section{Figure 3}

Precipitation time series in the Murrumbidgee River catchment area. JJAS precipitation at, a Burrinjuck Dam from 1910-2019, b Blowering Dam from 1955-2019 and c Tumut from 1883-2019; April-May precipitation at, d Burrinjuck Dam from 1910-2019, e Blowering Dam from 1955-2019 and, $f$ Tumut from 1883-2019. Dashed lines indicate percentiles 5th and 95th (red); 10th and 90th (orange); 15th and 85th (light blue); 20th and 80th (brown); and 25th and 75th (dark blue). 
Bootstrapped Blowering April and May Precipitation

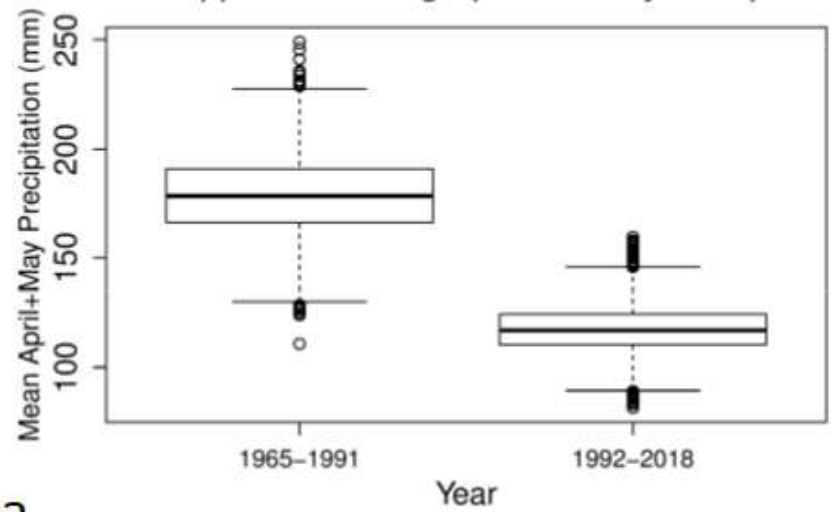

a

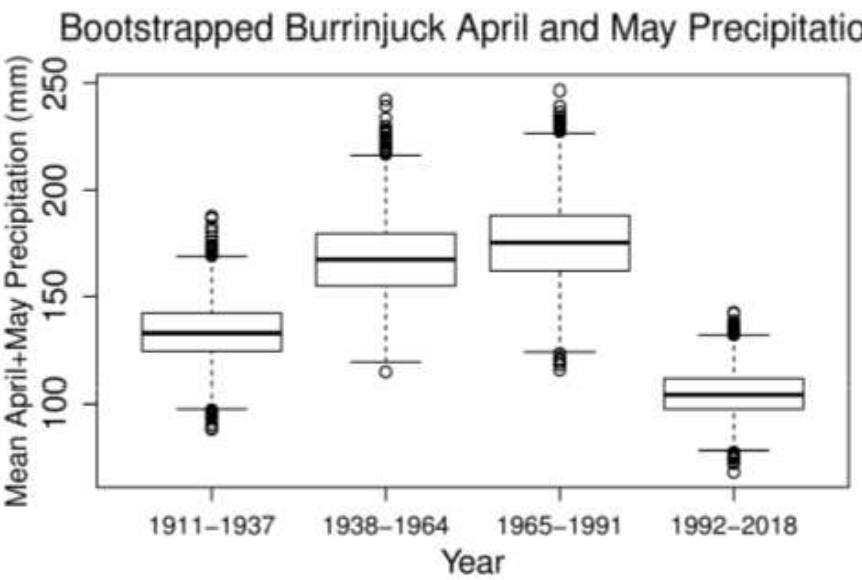

b
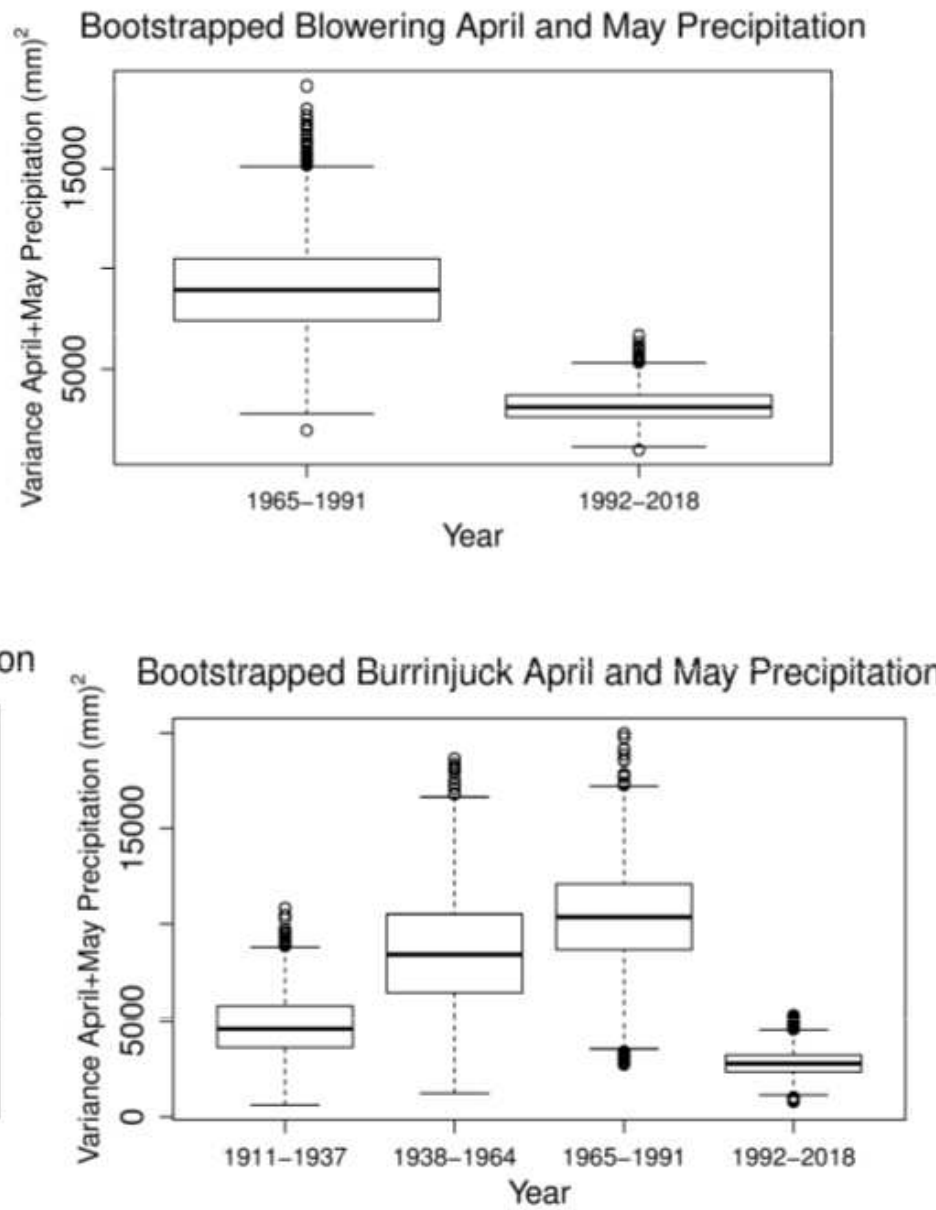

c

Bootstrapped Tumut April and May Precipitation

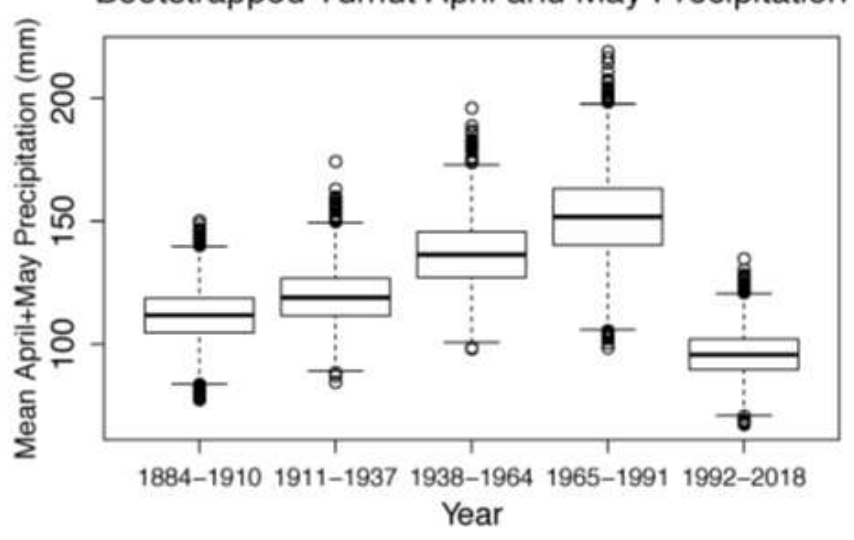

Bootstrapped Tumut April and May Precipitation

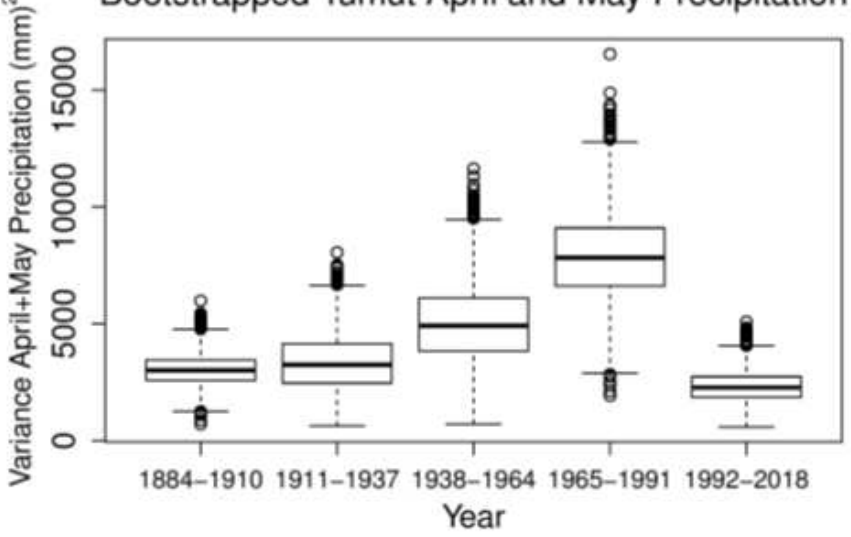

\section{Figure 4}

Box and whisker plots representing mean and variance of April-May catchment precipitation. Bootstrapped 27-year intervals of mean (left panel) and variance (right panel) of April-May precipitation for, a Blowering Dam, b Burrinjuck Dam, c Tumut. 


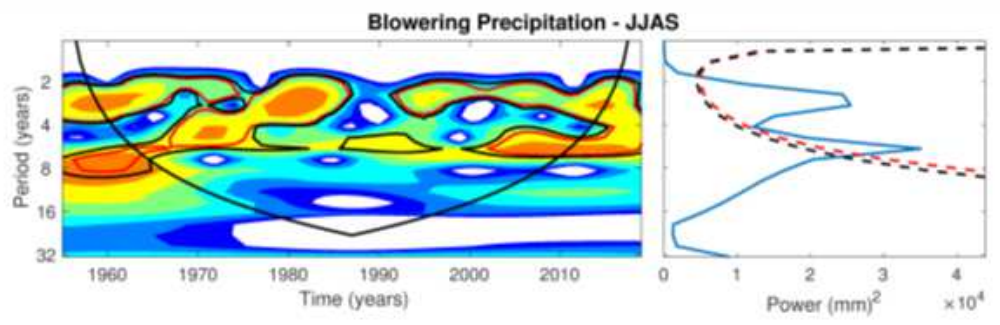

a

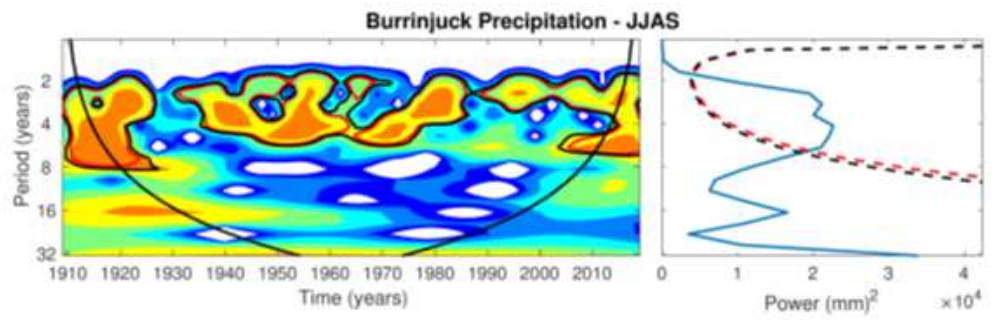

b

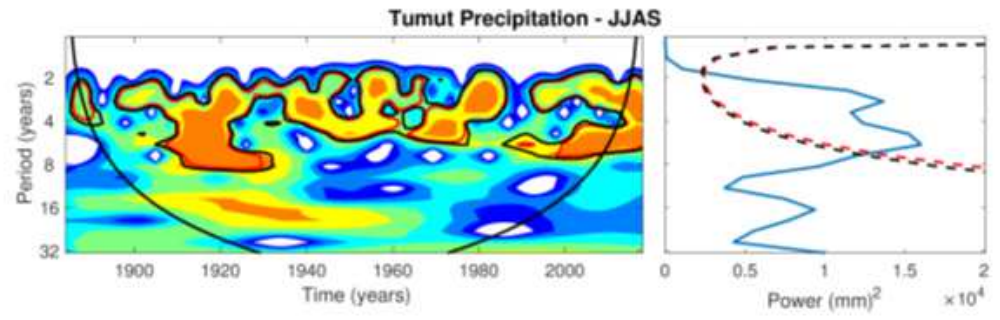

C

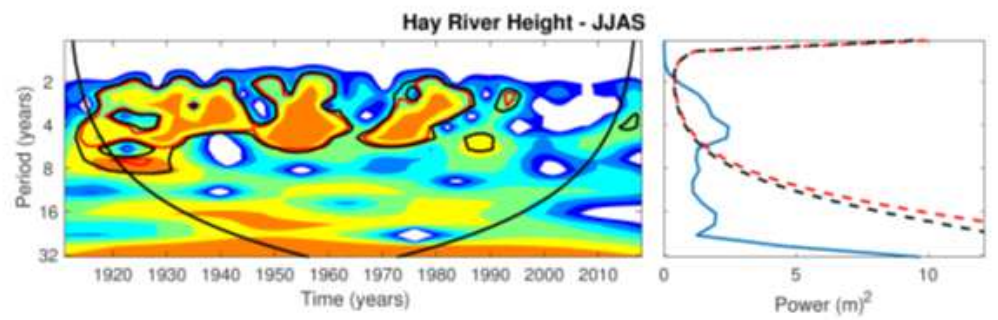

d

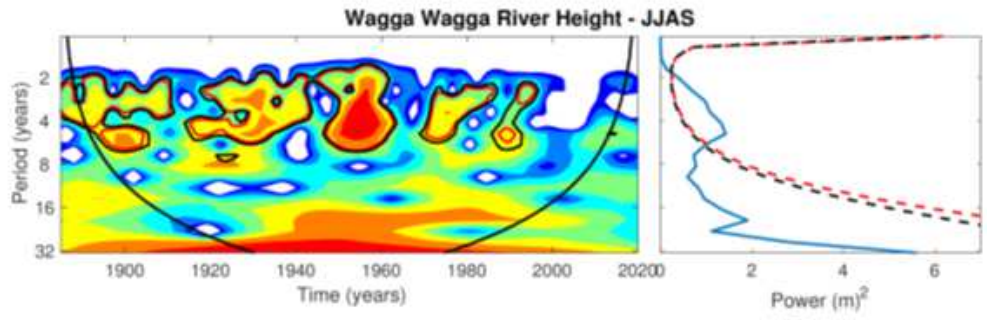

e

\section{Figure 5}

Wavelets of JJAS precipitation and river height. JJAS wavelets and global power spectra of precipitation for, a Burrinjuck Dam, b Blowering Dam, c Tumut; and d JJAS mean weekly Murrumbidgee river heights at Hay. Power significance is indicated by areas within thick black or red contours the $5 \%$ or $10 \%$ confidence levels, respectively. 

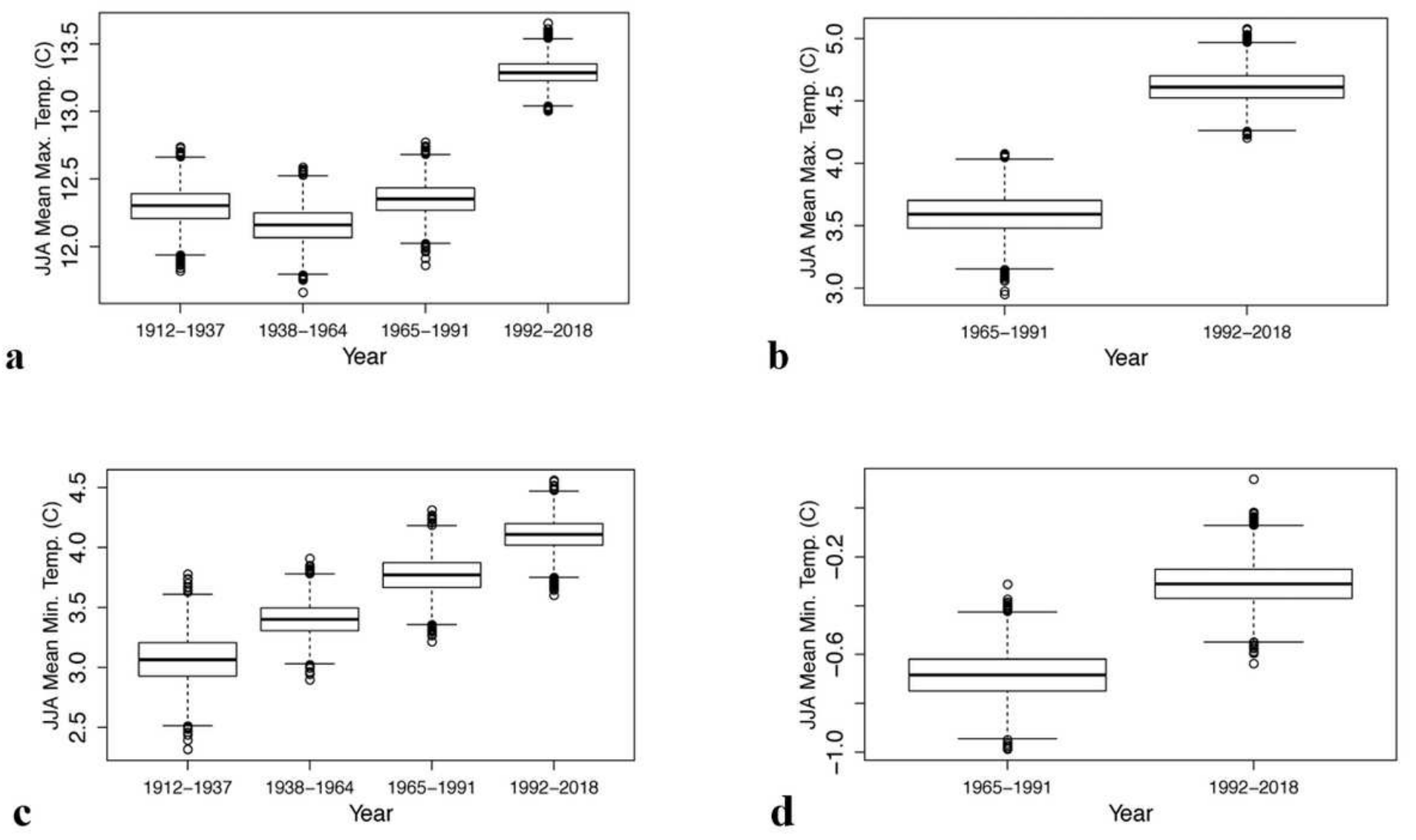

Figure 6

Box and whisker plots of mean temperature in the Murrumbidgee River catchment. a Bootstrapped 27year interval Burrinjuck JJA mean TMax (OC), b bootstrapped 27-year interval Cabramurra JJA mean TMax (OC), c bootstrapped 27-year interval Burrinjuck Dam JJA mean TMin (OC), and d bootstrapped 27year interval Cabramurra JJA mean TMin (OC). 